San Jose State University

SJSU ScholarWorks

Master's Theses

Master's Theses and Graduate Research

Spring 2012

\title{
Luminescence studies of Europium (III) - D-glucosamine complexes in water
}

Triny Trinh Pham

San Jose State University

Follow this and additional works at: https://scholarworks.sjsu.edu/etd_theses

\section{Recommended Citation}

Pham, Triny Trinh, "Luminescence studies of Europium (III) - D-glucosamine complexes in water" (2012). Master's Theses. 4159.

DOI: https://doi.org/10.31979/etd.ynu7-ejaj

https://scholarworks.sjsu.edu/etd_theses/4159

This Thesis is brought to you for free and open access by the Master's Theses and Graduate Research at SJSU ScholarWorks. It has been accepted for inclusion in Master's Theses by an authorized administrator of SJSU ScholarWorks. For more information, please contact scholarworks@sjsu.edu. 


\title{
LUMINESCENCE STUDIES OF EUROPIUM (III) - D-GLUCOSAMINE COMPLEXES IN WATER
}

\author{
A Thesis \\ Presented to \\ The Faculty of the Department of Chemistry \\ San Jose State University \\ In Partial Fulfillment \\ of the Requirements for the Degree \\ Master of Science
}

by

Triny Trinh Pham

May 2012 
(C) 2012

Triny Trinh Pham

ALL RIGHTS RESERVED 
The Designated Thesis Committee Approves the Thesis Titled

LUMINESCENCE STUDIES OF EUROPIUM (III) - D-GLUCOSAMINE COMPLEXES IN WATER

by

Triny Trinh Pham

APPROVED FOR THE DEPARTMENT OF CHEMISTRY

SAN JOSÉ STATE UNIVERSITY

May 2012

$\begin{array}{ll}\text { Dr. Herbert Silber } & \text { Department of Chemistry } \\ \text { Dr. Roger Terrill } & \text { Department of Chemistry } \\ \text { Dr. Karen Singmaster } & \text { Department of Chemistry }\end{array}$ 


\title{
ABSTRACT \\ LUMINESCENCE STUDIES OF EUROPIUM(III) - D-GLUCOSAMINE COMPLEXES IN WATER
}

\author{
by Triny Trinh Pham
}

Lanthanide complexation interactions measured by luminescence have become interesting topic in recent years. Europium is a rare earth metal and the $\mathrm{Eu}(\mathrm{III})$ ion is a hard acid; when $\mathrm{Eu}(\mathrm{III})$ and a monosaccharide ligand are present, a complex may be formed. The goal is to determine the equilibrium constant $\mathrm{K}_{\mathrm{EuL}}$ between the europium ion and a D-glucosamine ligand. At $25^{\circ} \mathrm{C}$ and $\mathrm{pH} \sim 7.40$, a physiologically important $\mathrm{pH}$, adding D-glucosamine enhanced the luminescence of $0.0025 \mathrm{M} \mathrm{Eu(III).} \mathrm{As} \mathrm{the}$ concentration of ligand increased, the emission intensity was also increased. The measurement of a hypersensitive peak at $614 \mathrm{~nm}$ indicated a complex reaction at $\mathrm{pH} \sim 7.40$. The equilibrium constant of $K_{E u L}$ was found to be 29.24. Based on the FTIR and laser experiments, the results confirmed that D-glucosamine attached to the europium ion $\left(\mathrm{Eu}^{3+}\right)$ at $\mathrm{pH} \sim 7.40$; there was no evidence that hydrolyzed $\mathrm{Eu}(\mathrm{III})$ was present in the complexation. 


\section{ACKNOWLEDGEMENTS}

I sincerely give my thanks to my research advisor, Dr. Herbert Silber, for affording me the opportunity to be part of the Silber group. Thank you for guidance, patience, and humor. My special thanks to my former colleague, Victor Maraschin. Thank you for the help with the luminescence instrument. Thanks to Mike Stephens, the instrument technician, for instructing and helping me to use the FTIR spectrometer. Thanks to Dr. Roger Terrill for providing the aqueous Zinc selenide cell for FTIR scanning. Without his help, this thesis would have never been completed. Thanks to Dr. Gilles Muller for allowing me to use the laser instrument and helping interpret the data. Thanks to Dr. Karen Singsmaster for becoming my third committee member. Thanks to Dr. Tran (Ly-Le Tran, MD, JD, Fellow, the American College of Legal Medicine) and James Boyle for editing the thesis. Special thanks to my parents, Friendly Pham and Khai Nguyen, for giving me life, love, and support. Thanks to my brothers, Tuan Pham, David Pham, Andy Pham, Viet Pham, and Kevin Pham for their encouraging me to continue my schooling. To my friends, I wish to express my gratitude for your support and inspiration. 
TABLE OF CONTENTS

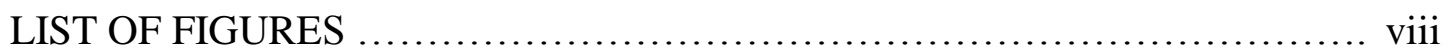

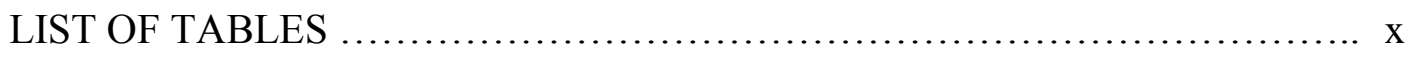

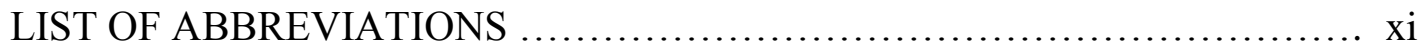

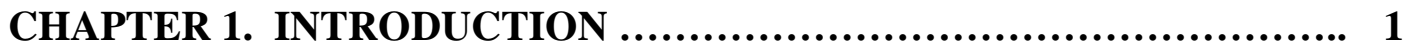
A. Background 1
B. Lanthanide Complexes with Luminescence ..................... 2
C. Europium Complexes with Luminescence $\ldots \ldots \ldots \ldots \ldots \ldots \ldots \ldots \ldots 2$
D. $\mathrm{pH}$ Dependence of Europium Luminescence..................... 5
E. Europium - Glucosamine Reaction............................. 5
F. Research Goals ........................................... 6

CHAPTER 2. EXPERIMENTAL METHODS ........................... 7

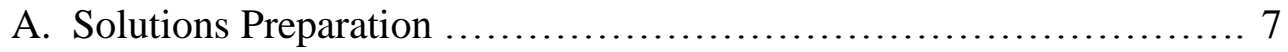

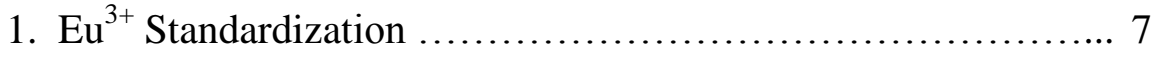

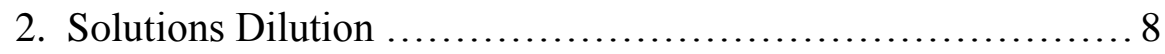

a. $\left[\mathrm{Eu}^{3+}\right]$ and $[\mathrm{D}$-glucosamine $]$ Dilutions ................ 9

b. Dilutions of Monosaccharide Solutions ................ 9

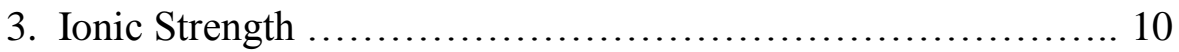

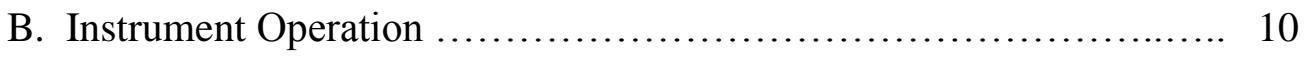


C. Equilibrium Constants Calculations .......................... 11

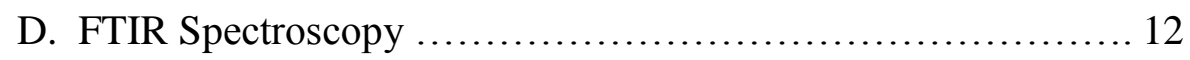

E. Laser Measurements .............................................13

CHAPTER 3. RESULTS AND DISCUSISON ............................ 14

A. Luminescence Measurements ........................................ 14

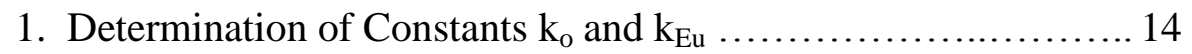

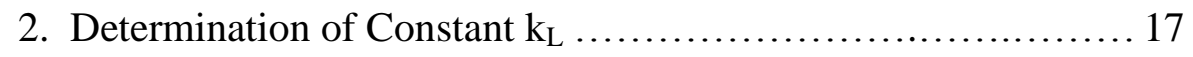

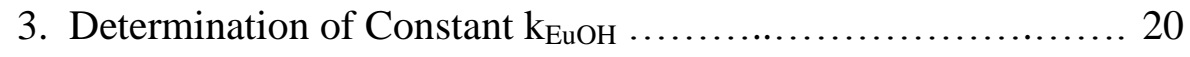

4. Determination of the Absence of EuOHL ...................... 22

a. FTIR Measurements ................................22

b. Excitation Measurements ...........................26

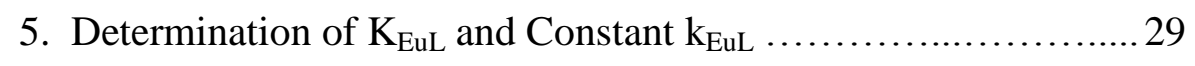

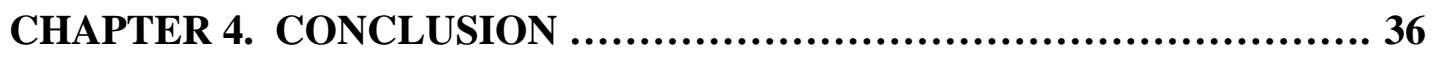

FUTURE STUDIES …......................................... 36

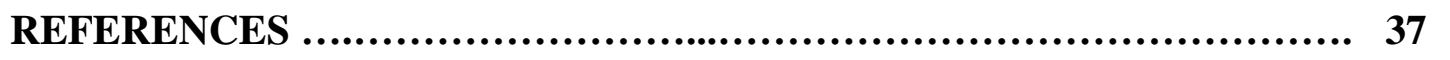

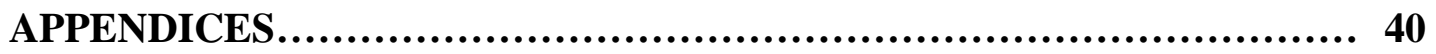

A. Instrumental Constants ................................................. 40

B. Ionic Strength ......................................................... 42

C. Additional Tables ....................................................43 


\section{LIST OF FIGURES}

Figure 1 Ionic strength dependence of the europium hydrolysis constant ............. 4

Figure 2 Europium-triflate $\left(\mathrm{Eu}(\text { trif })_{3}\right)$ solutions measured at $\mathrm{pH}<5.0$ and

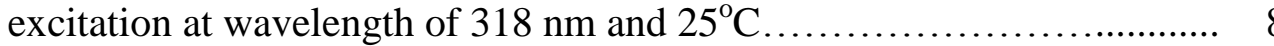

Figure 3 Linear regression line at low $\mathrm{pH}(\mathrm{pH}<5.0)$ of Eu(trif $)_{3}$ at wavelength of $614 \mathrm{~nm}$.

Figure $4 \mathrm{Eu}(\mathrm{III})-\mathrm{D}$-glucosamine reaction at $\mathrm{pH}<5.0$ and at constant europium concentration ................................................. 17

Figure 5 Luminescence spectra of Eu(III)-D-glucosamine complex at emission intensity as a function a wavelength at $\mathrm{pH} \sim 7.40$ and $25^{\circ} \mathrm{C} \ldots \ldots \ldots \ldots . .18$

Figure 6 Emission intensity versus [D-glucosamine] at difference $\mathrm{pH}$ and at wavelength of $614 \mathrm{~nm}$.

Figure 7 Observation of different monosaccharide ligands at $\mathrm{pH} \sim 7.40 . \ldots \ldots \ldots .20$

Figure 8 FTIR spectrum shows a $0.100 \mathrm{M} \mathrm{Eu(trif)})_{3}$ at $\mathrm{pH} \sim 7.40 \ldots \ldots \ldots \ldots \ldots \ldots \ldots . .23$

Figure 9 FTIR spectrum shows a $0.100 \mathrm{M}$ D-glucosamine at $\mathrm{pH} \sim 7.40 \ldots \ldots \ldots \ldots .24$

Figure 10 FTIR spectrum of a $0.100 \mathrm{M} \mathrm{Eu(trif)})_{3}: 0.100 \mathrm{M}$ D-glucosamine at $\mathrm{pH} \sim$ 7.40 .

Figure 11 Excitation measurements of $0.100 \mathrm{M} \mathrm{Eu(trif)})_{3}$ with and without $0.100 \mathrm{M}$ $\mathrm{NaClO}_{4}$ at $\mathrm{pH} \sim 7.40$.

Figure 12 Excitation measurements of $0.100 \mathrm{M} \mathrm{Eu}(\text { trif })_{3}+0.100 \mathrm{M} \mathrm{D}$-glucosamine with $0.100 \mathrm{M} \mathrm{NaClO}_{4}$ at $\mathrm{pH} \sim 7.40$.

Figure 13 Luminescence Spectra of Eu(III) - D-glucosamine excitation at wavelength of $318 \mathrm{~nm}, \mathrm{pH} \sim 7.40$.

Figure 14 An $\mathrm{Eu}(\mathrm{III})-\mathrm{D}$-glucsosamine curve function at $\mathrm{pH} \sim 7.40$ and wavelength of $614 \mathrm{~nm}$ at $[\mathrm{Eu}]_{\mathrm{t}}=2.50 \times 10^{-3} \mathrm{M}$. 
Figure A calculated intensity (I') as a function of [EuL] (Eu(III) - D-

$15 \mathrm{a}$ glucosamine) when $\mathrm{K}_{\mathrm{EuL}}$ is assumed to be 100 .

Figure A calculated intensity (I') as a function of [EuL] (Eu(III) - D-

$15 \mathrm{~b}$ glucosamine) when $\mathrm{K}_{\mathrm{EuL}}$ is assumed to be 1 .

Figure A calculated intensity (I') as a function of [EuL] (Eu(III) - D-

$15 \mathrm{c}$ glucosamine) when $\mathrm{K}_{\mathrm{EuL}}$ is 29.24 , the best fit of the data at $25^{\circ} \mathrm{C}$

35 


\section{LIST OF TABLES}

Table 1: $\quad$ Stock Solution Dilutions........................................ 43

Table 2: Initial Data Points of 0.0025M Eu(III)-D-

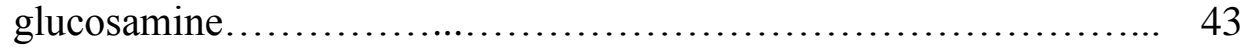

Table 3: Initial Data Points of 0.0025 M Eu(III) - Monosaccharide at $\mathrm{pH}$

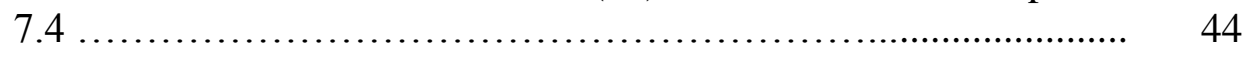

Table 4: $\quad$ Europium Constant, $\mathrm{K}_{\mathrm{EuL}}$, of Each Monosaccharide Ligand............... 21

Table 5: Data Points of 0.0025 M Eu(III) - D-glucosamine at wavelength of

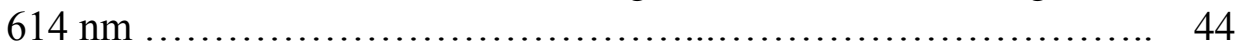




\section{LIST OF ABBREVIATIONS}

BSA

$\mathrm{CF}_{3} \mathrm{SO}_{3}{ }^{-}$

$\mathrm{CF}_{3} \mathrm{SO}_{3} \mathrm{H}$

Constant

EDTA

Equilibrium

$\mathrm{Eu}(\text { trif })_{3}$

$\mathrm{Eu}_{2} \mathrm{O}_{3}$

[EuL]

FTIR

GM1

$\mathrm{HCl}$

LASER

M

$\mathrm{mg}$

$\mathrm{mL}$

$\mathrm{NaClO}_{4}$

$\mathrm{NaOH}$

$\mathrm{Nd}(\mathrm{III})$

$\mathrm{nm}$

NMR
Bovine serum albumin

Triflate or trifluoromethanesulfonate

Triflic acid or trifluoromethanesulfonic acid

Ethylenediaminetetraacetic acid

K (unitless)

Europium(III) triflate

Europium (III) oxide

Europium-Ligand concentration

Fourier Transform Infrared

Monosialoganglioside

Hydrogen chloride (hydrochloric acid)

Light Amplification by Stimulated Emission of Radiation

Molarity (moles/L)

milligram

milliliter

Sodium perchlorate

Sodium hydroxide

Neodymium

nanometer $\left(10^{-9} \mathrm{~m}\right)$

Nuclear Magnetic Resonance 


$\begin{array}{ll}\mathrm{NO}_{3}{ }^{-} & \text {Nitrate } \\ \text { NSAIDs } & \text { Non-Steroidal Anti-Inflammatory Drugs } \\ \mathrm{OTf}^{-} & \text {Triflate } \\ \mathrm{SCN}^{-} & \text {Thiocyanate } \\ \text { TMJ } & \text { Temporo-mandibular Joint }\end{array}$




\section{Chapter 1}

\section{Introduction}

\section{A. Background}

Luminescence, one of the most sensitive spectroscopic techniques, was first discovered by the Irish scientist George Gabriel Stokes (Stokes, 1852). Lanthanide luminescence depends on the contribution of a hypersensitive peak which responds to the environment of lanthanide metal ions. A recent study has shown that europium (III) binds to carbohydrate ligands at a pH of $~ 7.5$ (Leonard, et al., 2007). Lanthanide-ligand complexes may have strong $\mathrm{pH}$-dependent interactions, which can be recorded at various emission wavelengths to determine the hypersensitivity of each complex sample.

Luminescent emission can be detected at times ranging from a few nanoseconds to milliseconds (Hedinger, et al., 1998), and luminescence can be fluorescence or phosphorescence. With regard to phosphorescence, the light absorption causes electronic transitions between different multiplicity levels, and emission persists for $10^{-3}-10 \mathrm{~s}$ (Hamilton, 2003). When the luminescence of a europium-ligand complex is measured, four sharp peaks are detected at $\mathrm{J}=1,2,3$, and 4 , the transition peaks are assigned to the ${ }^{5} \mathrm{D}_{0} \rightarrow{ }^{7} \mathrm{~F}_{1},{ }^{5} \mathrm{D}_{0} \rightarrow{ }^{7} \mathrm{~F}_{2},{ }^{5} \mathrm{D}_{0} \rightarrow{ }^{7} \mathrm{~F}_{3}$, and ${ }^{5} \mathrm{D}_{0} \rightarrow{ }^{7} \mathrm{~F}_{4}$ transitions, respectively (Leonard, et al., 2007 \& Skoog, et al., 1998). Leonard et al. (2007) showed that a lanthanide complex exhibits four transitions and the hypersensitive peak has a wavelength of $615 \mathrm{~nm}$. The hypersensitive peak is assigned to a ${ }^{5} \mathrm{D}_{0} \rightarrow{ }^{7} \mathrm{~F}_{2}$ transition and appears at an emission wavelength of $615 \mathrm{~nm}$. 


\section{B. Lanthanide Complexes with Luminescence}

The transition energies of lanthanide metal ions are described and illustrated in the form of an energy diagram, and (Skoog, et al., 1998 \& Yang, et al., 2004) most lanthanide peaks, except for the hypersensitive peaks, are insensitive to their environment. If a complexation occurs, the hypersensitive peak increases in emission intensity as a function of increased ligand concentrations. Studies have shown that lanthanides, such as neodymium (III), erbium (III), and ytterbium (III), are sensitized when complexed and exhibit a near-infrared luminescence (Hedinger, et al., 1998). Biological experiments like fluoro-immunoassays (Bucella, et al., 2004, Sherry, et al., 1973, Atkinson, et al., 2005, Silber, et al., 2001, \& Silber and Nguyen, 1998) and microscopy (Alpturk, et al., 2006 \& Diaz and Berger, 2000) have been used for autofluorescence (Hedinger, et al., 1998). Other lanthanides that luminesce in the visible region are europium (III) and terbium (III). These lanthanide complexes can also be studied in biological assays.

\section{Europium Complexes with Luminescence}

Monosaccharide ligands (simple sugars) react with lanthanides and have recently been studied in europium complexes (Alekseev, et al., 1998). Alptürk et al. (2006)

reported that a single sugar ligand interacts with $\mathrm{Eu}^{3+}$ at $\mathrm{pH} 7.0$ and has an emission wavelength of $615 \mathrm{~nm}$. During the interaction of metal (M) and ligand (L), the metal and ligand complex (ML) is formed: 


$$
\begin{array}{ll}
1.1 & \mathrm{M}^{+}+\mathrm{L}^{-} \rightleftharpoons \mathrm{M}-\mathrm{L} \\
1.2 & \mathrm{~K}_{\mathrm{eq}}=\frac{[\mathrm{M}-\mathrm{L}]}{\left[\mathrm{M}^{+}\right] \times\left[\mathrm{L}^{-}\right]}
\end{array}
$$

For the formation of a metal-ligand complex, it is important to consider the $\mathrm{pH}$ dependence of the luminescence intensity. $\mathrm{Eu}^{3+}$ luminescence spectra exhibit specific emission peaks at 590,614, 649, and $695 \mathrm{~nm}$, and many lanthanide complexes are formed below a $\mathrm{pH}$ of 5 . Luminescence spectra indicate that the hypersensitive peak at $614 \mathrm{~nm}$ changes in emission intensity as ligand concentrations change. This emission intensity increases as the concentration of ligand increases at $\mathrm{pH} \sim 7.40$ (Leonard, et al., 2007).

The first hydrolysis constant was studied by the Ramírez-Garcia et al. (2003) and Bentouhami et al. (2004) as:

$$
\begin{aligned}
& 1.3 \mathrm{Eu}^{3+}+\mathrm{H}_{2} \mathrm{O} \rightleftharpoons \mathrm{Eu}(\mathrm{OH})^{2+}+\mathrm{H}^{+} \\
& 1.4 \quad \mathrm{~K}=\frac{\left.\left[\mathrm{Eu}(\mathrm{OH})^{2+}\right] \times \mathrm{H}^{+}\right]}{\left[\mathrm{Eu}^{3+}\right]}
\end{aligned}
$$

Lopéz-González et al. (2007) performed a recent study of the hydrolysis constant reaction. The authors showed that the hydrolysis equilibrium constant $K_{O H}$ was obtained from the basic hydrolysis reaction (Equation 1.4) to form a europium ion complex. 
In Figure 1, the Eu (III) hydrolysis constant is plotted as a function of ionic strength (Jimenez-Reyes, et al., 2006) From this graph, $p K_{O H}$ at ionic strength of 0.10 Molar $\left(\mathrm{NaClO}_{4}\right)$ is 7.41 at $25^{\circ} \mathrm{C}$.

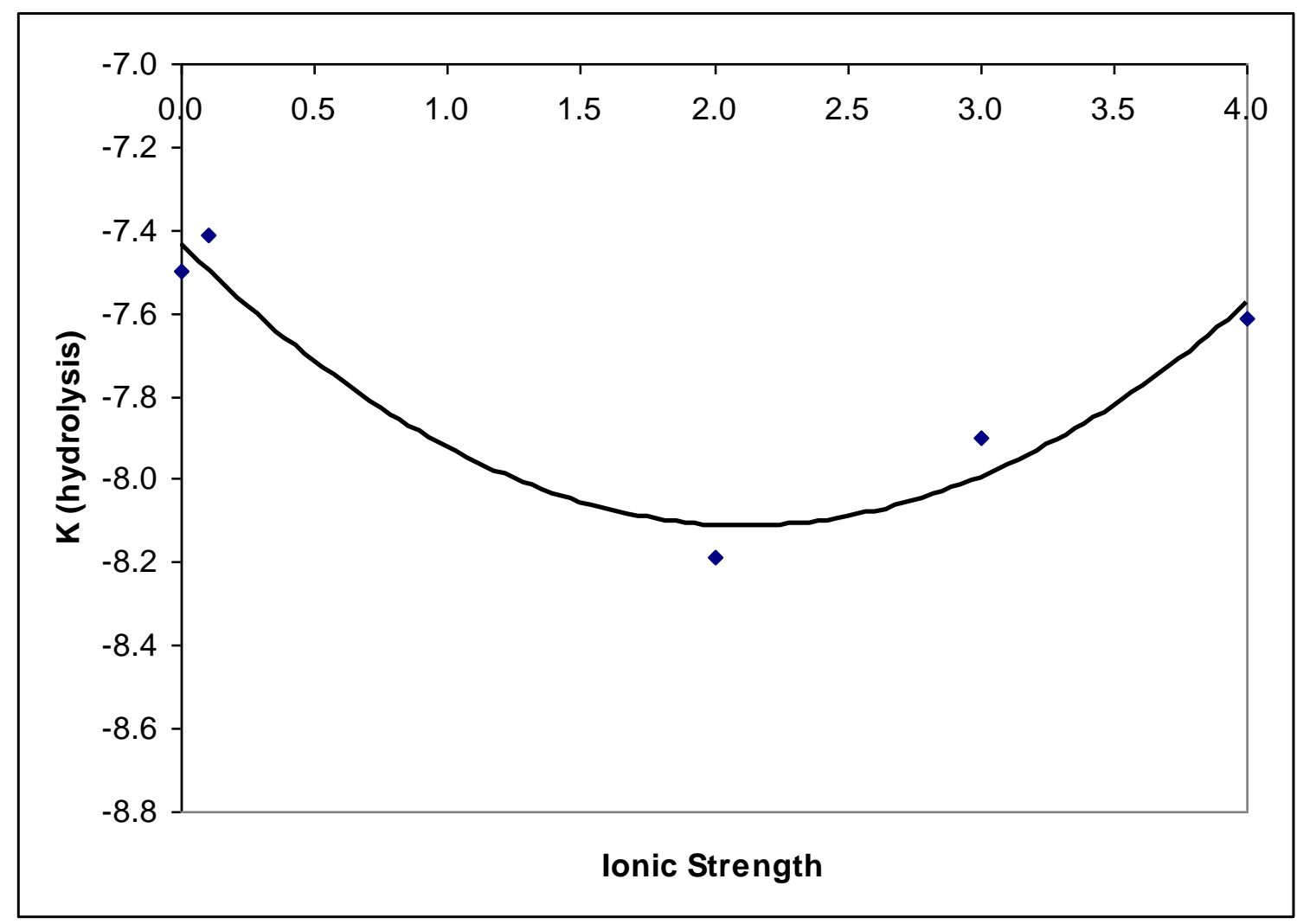

Figure 1. Ionic strength-dependence of the europium hydrolysis constant.

The europium stability constant is substantially influenced by ionic strength. Ionic strength, $I$, is a measurement of the concentrations of all ions in a solution.

$$
1.5 \quad \mathrm{I}=\frac{1}{2} \sum\left(\mathrm{Z}_{\mathrm{i}}^{2}+\mathrm{C}_{\mathrm{i}}\right)
$$

where $Z_{i}$ and $C_{i}$ are the charges and concentrations of individual species, respectively. 


\section{D. pH Dependence of Europium Luminescence}

Parker and $\mathrm{Yu}$ (2005) studied the europium-citrate complex at $\mathrm{pH}=7.40$ and emission wavelength of $616 \mathrm{~nm}$. They showed that citrate reacted with europium to form a Eu(III) - citrate complex. Hedinger et al. (1998) confirmed that $\mathrm{Eu}^{3+}$ binds to a trinuclear lanthanoid complexes of 1,3,5-triamino-1,3,5-trideoxy-cis-inositol (TACI) between the $\mathrm{pH}$ of 7 and 9 . In the absence of a complexing ligand, the emission intensity is described as:

$$
\text { 1.6 } \quad \mathrm{I}_{\mathrm{o}}=\mathrm{k}_{\mathrm{o}}+\mathrm{k}_{\mathrm{Eu}}[\mathrm{Eu}]
$$

where $k_{o}$ is the intensity constant due to the instrument and the solvent, and $k_{E u}$ is the free europium constant at low $\mathrm{pH}$. Then at $\mathrm{pH} \sim 7.40$, europium is hydrolyzed to:

$$
1.7 \quad \mathrm{I}=\mathrm{k}_{\mathrm{o}}+\mathrm{k}_{\mathrm{Eu}}[\mathrm{Eu}]+\mathrm{k}_{\mathrm{EuOH}}[\mathrm{EuOH}]
$$

where $\left[\mathrm{EuOH}^{2+}\right]$ can be calculated from the hydrolysis reaction (Equation 1.3). In Equation 1.7, the instrument constants, $k_{o}$ and $k_{E u}$ are obtained from the emission intensity of a sample. The constant $k_{E u O H}$ is used to confirm the calculation of $K_{O H}$ from the hydrolysis reaction. However, in the absence of ligand at $\mathrm{pH} \sim 7.40$, substantial $\mathrm{Eu}(\mathrm{OH})_{3}$ may be present.

\section{E. Europium - Glucosamine Reaction}

At neutral $\mathrm{pH} \sim 7.40$, the Europium-glucosamine interaction is detected at the hypersensitive emission peak at $614 \mathrm{~nm}$. The complexation is written as: 


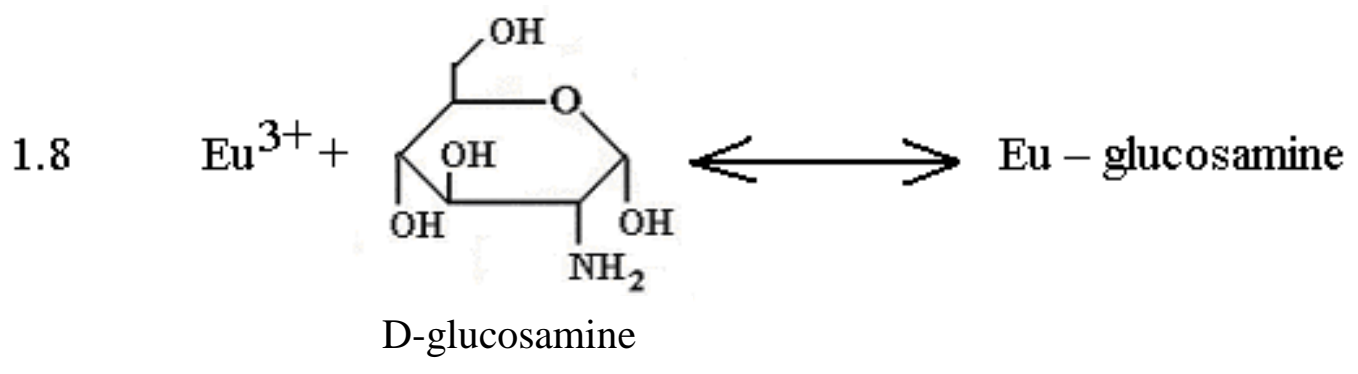

Bonding interactions of this europium complex will be studied further using FTIR and laser excitation spectroscopy.

\section{F. Research Goals}

The objective of this thesis was to determine the equilibrium constant, $K_{E u L}$, of europium (III) and D-glucosamine at physiological $\mathrm{pH}$ using luminescence at a hypersensitive transition. The experiments were conducted to understand whether D-glucosamine ligand binds to free europium $\left(\mathrm{Eu}^{3+}\right)$ or to europium hydroxide $\left(\mathrm{EuOH}^{2+}\right)$ at $\mathrm{pH} \sim 7.40$. The data demonstrated that adding ligand to europium increased the luminescence intensity. The experimental data presented describes the peak sensitivity and the lanthanide complex interaction that allows the calculation of the equilibrium constant. The Eu-glucosamine contained the amino group at $\mathrm{C}_{2}$ and the hydroxyl groups at $\mathrm{C}_{1}$ and $\mathrm{C}_{3}$ of $\mathrm{D}$-glucosamine did bind to $\mathrm{Eu}^{3+}$, but did not bind to $\mathrm{EuOH}^{2+}$ due to ionic interactions. FTIR and laser excitation measurements provide the evidence that $\mathrm{Eu}^{3+}$ binds to D-glucosamine. 


\section{CHAPTER 2}

\section{Experimental Methods}

\section{A. Solutions Preparation}

Europium oxide $\left(\mathrm{Eu}_{2} \mathrm{O}_{3}\right)$ powder was purchased from Standford Materials Corporation at Irvine, California (99.99\% assay), and trifluoromethanesulfonic acid $\left(\mathrm{CF}_{3} \mathrm{SO}_{3} \mathrm{H}\right.$ or triflic acid) was purchased from Alfa Aesar at Ward Hill, Massachusetts (99\% assay) and utilized without further purification. A stock solution of $5.049 \times 10^{-2} \mathrm{M}$ $\mathrm{Eu}(\text { trif })_{3}$ was manually prepared from a white solid $\mathrm{Eu}_{2} \mathrm{O}_{3}$ and triflic acid in deionized water. Prior to the analyses, all necessary glassware was washed and dried in an oven. After drying, $0.880 \mathrm{~g}$ of $\mathrm{Eu}_{2} \mathrm{O}_{3}$ powder and $1.328 \mathrm{ml}$ of triflic acid were slowly dissolved in distilled water under agitation. This process was done under a fume hood because the reactions between $\mathrm{Eu}_{2} \mathrm{O}_{3}$ and triflic acid give off heat. A $9.701 \times 10^{-3} \mathrm{M}$ ethylenediaminetetraacetic acid (EDTA) solution was also made to standardize the Eu(trif) ${ }_{3}$ solution. EDTA (3.722 g) solid was dissolved in $100 \mathrm{ml}$ of deionized water. All of the above solutions were manually prepared from solid reagents at room temperature.

\section{1. $\mathbf{E u}^{3+}$ Standardization}

After $5.049 \times 10^{-2} \mathrm{M}\left[\mathrm{Eu}(\text { trif) })_{3}\right]$ (alternately known as $\left[\mathrm{Eu}^{3+}\right]$ ) stock solution was prepared, titration was done to standardize $\left[\mathrm{Eu}^{3+}\right]$ concentration. $0.300 \mathrm{~mL}$ of $5.049 \times 10^{-2} \mathrm{M} \mathrm{Eu}^{3+}$ was mixed with 3 drops of bromopyrogallol indicator and 1-2 $\mathrm{g}$ of sodium acetate and $10 \mathrm{~mL}$ deionized water. Titration was done using $9.701 \times 10^{-3} \mathrm{M}$ EDTA. When the indicator was added to the $\mathrm{Eu}^{3+}$ solution, it turned purple. At the 
endpoint of titration, the purple color had changed to pink. Approximately four to five titration trials were performed and the average net concentration was found to be $0.050 \pm 0.001 \mathrm{M}$

\section{Solutions Dilution}

From the above $\mathrm{Eu}^{3+}$ stock solution, eight different concentrations were prepared ranging from $5.00 \times 10^{-4} \mathrm{M}$ to $4.00 \times 10^{-3} \mathrm{M}$. After eight samples were completely diluted, luminescence data were collected. Emission intensity (Figure 2) was used to prepare a calibration plot as a function of $\mathrm{Eu}^{3+}$ concentrations.

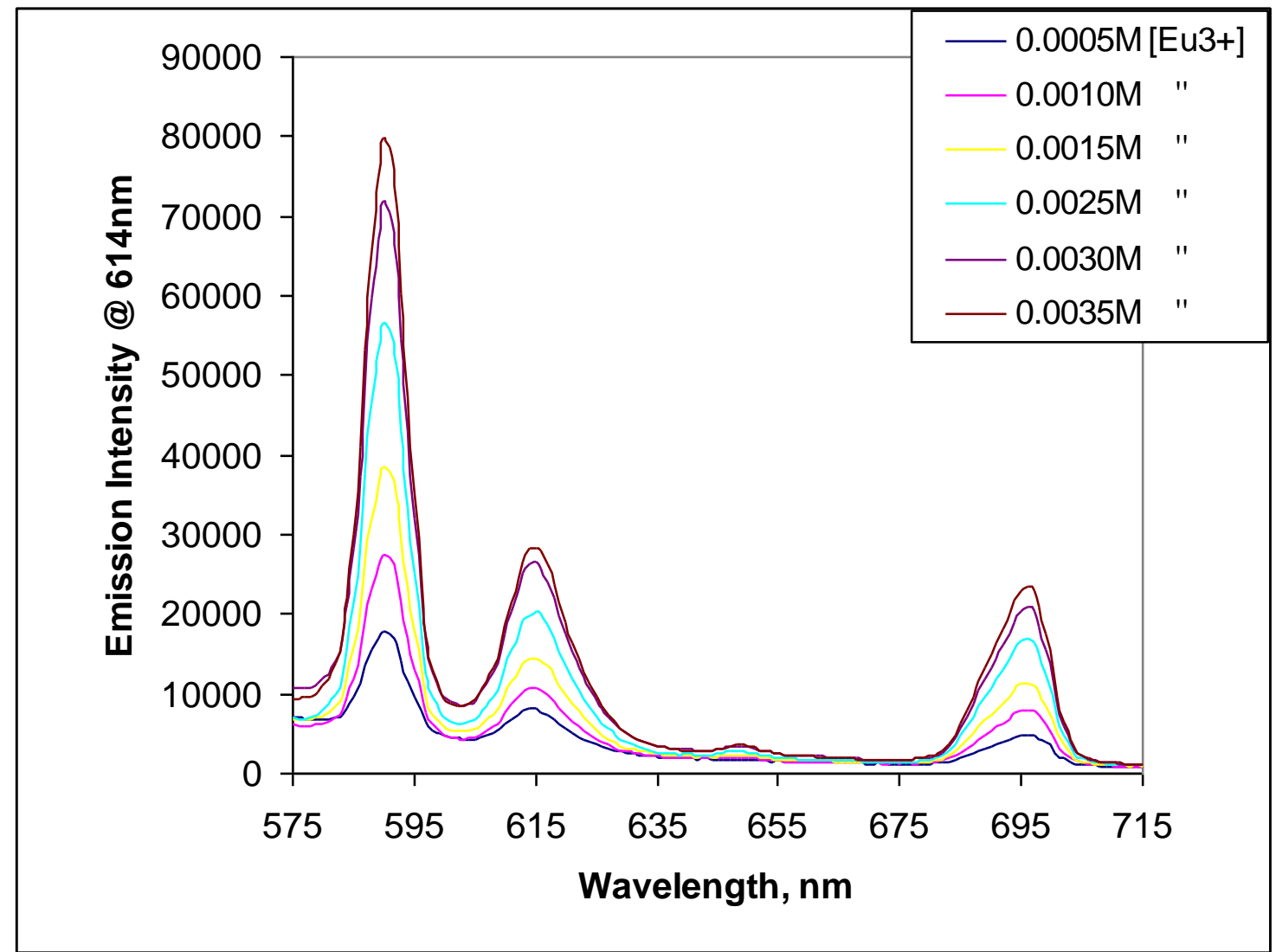

Figure 2. Europium-triflate $\left(\mathrm{Eu}(\text { trif })_{3}\right)$ solutions measured at $\mathrm{pH}<5.0$ and excitation at wavelength of $318 \mathrm{~nm}$ and $25^{\circ} \mathrm{C}$. 


\section{a. $\left[\mathrm{Eu}^{3+}\right]$ and $[\mathrm{D}$-glucosamine $]$ dilutions}

A stock [D-glucosamine] solution was made at $0.100 \mathrm{M}$, and a $2.00 \mathrm{M}$ sodium perchlorate $\mathrm{NaClO}_{4}$ solution was also prepared. A target concentration was selected to be $2.50 \times 10^{-3} \mathrm{M}$ for $\mathrm{Eu}^{3+}$ and $0.085 \mathrm{M}$ for $\mathrm{NaClO}_{4}$. D-glucosamine (2.156 g) solid was diluted with deionized water to make a $0.100 \mathrm{M}$ [D-glucosamine] stock solution. Multiple D-glucosamine solutions were prepared ranging from $7.60 \times 10^{-4} \mathrm{M}$ to $2.50 \times 10^{-2} \mathrm{M}$. A quantity of $24.492 \mathrm{~g} \mathrm{NaClO}_{4}$ solid was diluted to make a $2.00 \mathrm{M}$ $\mathrm{NaClO}_{4}$ stock solution. Then $0.425 \mathrm{~mL}$ of a $2.00 \mathrm{M} \mathrm{NaClO}_{4}$ solution was added to each of the solution samples to stabilize the ionic strength. Table 1 of the Appendix $\mathrm{C}$ shows descriptive details on solution dilution. The $5.00 \times 10^{-2} \mathrm{M}$ sodium hydroxide $(\mathrm{NaOH})$ solution was also made to adjust each sample to $\mathrm{pH} \sim 7.40$.

\section{b. Dilutions of monosaccharide solutions}

$\mathrm{Eu}^{3+}$ and D-glucosamine samples were measured at excitation wavelengths of $318 \mathrm{~nm}$ and an emission wavelength of $614 \mathrm{~nm}$ at $25^{\circ} \mathrm{C}$. Data on other sugars such as galactose, ribose, and mannose were also collected to measure average intensity (Equation 1.7). A $0.100 \mathrm{M}$ concentration of each sugar was diluted. The same dilution method was used to prepare each sugar solution, and $5.00 \times 10^{-2} \mathrm{M} \mathrm{NaOH}$ was used to adjust each sample to $\mathrm{pH} \sim 7.40$. These diluted solutions were then ready for measurement of emission intensity. The emission wavelength was arranged between 590 and $715 \mathrm{~nm}$ for each luminescence measurement. 


\section{Ionic Strength}

Sodium perchlorate $\mathrm{NaClO}_{4}$ was used in the $\mathrm{Eu}^{3+}$ solution to adjust ionic strength. Since the target $\left[\mathrm{Eu}^{3+}\right]$ was $2.50 \times 10^{-3} \mathrm{M}$ and the total ionic strength in $\mathrm{a}\left[\mathrm{Eu}^{3+}\right]$ solution is $0.100 \mathrm{M}$, then ionic strength, $I$, was calculated as:
2.1
$E u(t r i f)_{3} \rightarrow E u^{3+}+3$ trif $^{-}$
where $[$ trif $]=3\left[\mathbf{E u}^{3+}\right]$
$2.2 I=1 / 2 \Sigma\left(Z_{i}^{2} \times C_{i}\right)$
where $C_{E u}=0.0025 M$

When all constants were calculated, the ionic strength of $\mathrm{Eu}(\text { trif })_{3}$ was adjusted to $0.015 \mathrm{M}$ with $\mathrm{NaClO}_{4}$. The total ionic strength was therefore $0.100 \mathrm{M}$. The details of ionic strength are described in the Appendix B.

\section{B. Instrument Operation}

After $\mathrm{Eu}^{3+}$ and D-glucosamine solutions were prepared, luminescence (Fluorolog®-3) parameters were correctly set and a xenon lamp was chosen for the light source. Luminescence slit widths were set to $5 \mathrm{~nm}$, the excitation wavelength was set to $318 \mathrm{~nm}$ and the emission wavelength was set to $614 \mathrm{~nm}$. When all of the parameters were selected and ready to run, numbers of data of initial solutions were collected. Table 2 showed different emission intensities under low and high $\mathrm{pH}$ measurements. The emission intensity of lower $\mathrm{pH}$ solutions were always lower than that of higher $\mathrm{pH}$ solutions.

Using the same scanning method, luminescence data was also collected for other sugars. The recorded emission intensities (cps) at $614 \mathrm{~nm}$ of all four sugars were 
consistent throughout the scanning. The emission intensity was lower when the lifetime of the xenon lamp decreased; hence causing a discrepancy in data collection. To avoid this discrepancy, a lamp test scan was performed before starting to collect any luminescence data. After collecting data points of this set of initial solutions, more solutions were prepared at higher D-glucosamine concentrations. The findings are in the results and discussion chapter.

\section{Equilibrium Constants Calculations}

When intensity data for all concentrations were collected, the constants ( $k$ 's) were calculated using the equation:

$$
\begin{array}{r}
\quad \mathrm{I}=k_{o}+k_{E u}[\mathrm{Eu}]+k_{E u O H}[E u O H]+k_{E u L}[E u L]+k_{L}[L] \\
+k_{E u O H L}[E u O H L]
\end{array}
$$

Emission intensity, $I$, is collected from the luminescence instrument. When intensity $I$ is known, constant $k_{E u L}$ would be able to obtain a value by calculating from Equation 2.3.

As D-glucosamine was a ligand added to the $\left[\mathrm{Eu}^{3+}\right]$ solution, the equilibrium constant of EuL complex was given by:

$$
\begin{aligned}
& 2.4 \mathrm{Eu}+\mathrm{L} \rightleftharpoons \mathrm{EuL} \\
& 2.5 \quad \mathrm{~K}_{\mathrm{EuL}}=\frac{[\mathrm{EuL}]}{[\mathrm{Eu}] \times[\mathrm{L}]}
\end{aligned}
$$

Further calculations are presented in the Appendix A. 


\section{FTIR Spectroscopy}

Fourier transform infrared spectroscopy (FTIR) is a useful tool to identify functional groups of a chemical compound. When a chemical compound is observed with infrared radiation, vibrational motions can be observed (Skoog, et al., 1998). Under these circumstances, the radiation's electrical field interacts with the molecule in a way that changes the amplitude of the vibrational motions. In this study, spectra were collected between 500-4000 $\mathrm{cm}^{-1}$ using a Genesis II FTIR spectrometer, and the spectra were analyzed with WinFirst software.

A white europium trifluoromethanesulfonate $\left(\mathrm{Eu}(\mathrm{trif})_{3}, 98 \%\right.$ pure $)$ powder and D-glucosamine solid were purchased from Sigma Aldrich at St. Louis, Missouri. A ratio of $1: 1$ of $0.100 \mathrm{M} \mathrm{Eu}$ (trif) 3 to $0.100 \mathrm{M} \mathrm{D}$-glucosamine solution was prepared. The prepared stock concentrations for running FTIR were $1.00 \mathrm{M}$ for $\mathrm{Eu}(\operatorname{trif})_{3}, 1.00 \mathrm{M}$ for $\mathrm{D}$ glucosamine, and $2.00 \mathrm{M}$ for $\mathrm{NaClO}_{4}$. One $\mathrm{ml}$ of $1.00 \mathrm{M} \mathrm{Eu}$ (trif) $)_{3}, 1 \mathrm{~mL}$ of $1.00 \mathrm{M}$ D-glucosamine, and $0.500 \mathrm{~mL}$ of $2.00 \mathrm{M} \mathrm{NaClO}_{4}$ were transferred into a $10-\mathrm{mL}$ volumetric flask, then the solution was diluted to the mark using deionized water and $[\mathrm{NaOH}]$ solution to raise $\mathrm{pH}$ to 7.40 .

Separate solutions of $0.100 \mathrm{M}$ D-glucosamine and $0.100 \mathrm{M} \mathrm{Eu}(\text { trif })_{3}$ were made to run the spectra under $25^{\circ} \mathrm{C}$ for references. All solutions were measured at $\mathrm{pH} \sim 7.40$. A $1 \mathrm{~mL}$ of $1.00 \mathrm{M}$ D-glucosamine was pipetted in a 10-mL volumetric flask, and deionized water was added to the mark. One $\mathrm{mL}$ of $1.00 \mathrm{M} \mathrm{Eu(trif)})_{3}$ and $0.500 \mathrm{~mL}$ of $2.00 \mathrm{M}$ $\mathrm{NaClO}_{4}$ were transferred into a 10 -mL volumetric flask, then deionized water was added to the mark. A zinc selenide attenuated total reflection liquid cell was positioned in the FTIR's sample compartment to run the solutions. 


\section{E. Laser Measurements}

A laser was used to study chemical binding between Eu(III) and D-glucosamine groups. Laser excitation spectroscopy was used to induce the excitation of lanthanide ion $\left(\mathrm{Eu}^{3+}\right)$ from a ground state ${ }^{7} \mathrm{~F}_{0}$ to an excited state ${ }^{5} \mathrm{D}_{0}$ of the $4 \mathrm{f}^{6}$ electron configuration (Albin, Whittle, et al., 1985). The excitation was completed by using a dye laser spectrometer, and the emission was monitored at a corresponding ${ }^{5} \mathrm{D}_{0} \rightarrow{ }^{7} \mathrm{~F}_{2}$ energy transition at $614 \mathrm{~nm}$.

The procedures for 1:1 ratio sample preparation were similar to those used for the FTIR solution mixture at $\mathrm{pH} \sim 7.40$ and $\mathrm{pH} \sim 6.0$. The third Eu(trif) $)_{3}$ sample was prepared with the presence of $\mathrm{NaClO}_{4}$ at $\mathrm{pH} \sim 7.40$, and the fourth $\mathrm{Eu}(\text { trif })_{3}$ sample were made in the absence of $\mathrm{NaClO}_{4}$ at $\mathrm{pH} \sim 7.40$. Four spectra were observed and the intensity recorded as a function of wavelength $(\mathrm{nm})$ at $25^{\circ} \mathrm{C}$. 


\section{CHAPTER 3}

\section{Results and Discussion}

Emission intensity at high $\mathrm{pH}$ was formulated in Equation 2.3, and each constant,

$k$, was determined separately. The constant value $k_{o}$ was determined from both the instrument and solvent, whereas the constant $k_{E u}$ is the free europium constant. The constants $k_{o}+k_{E u}[\mathrm{Eu}]$ were determined at a low $\mathrm{pH}$ in the absence of ligand. The constant $k_{L}[\mathrm{~L}]$ represents the simple sugar (ligand); its value was negligible. Constant $k_{\mathrm{EuOH}}$ is determined from the average intensity of the four sugars, galactose, ribose, mannose, and D-glucosamine. The constant $k_{E u L}[\mathrm{EuL}]$ was calculated after a ligand was added to a $0.1 \mathrm{M} \mathrm{Eu(III)} \mathrm{solution.} \mathrm{Those} \mathrm{constants} \mathrm{were} \mathrm{a} \mathrm{function} \mathrm{of} \mathrm{instrument}$ wavelength, slit width, and so forth and were not fundamental constants. I will discuss the details of each individual physical term calculating the equilibrium constant from Equation 2.3.

\section{A. Luminescence Measurements}

\section{Determination of Constants $\boldsymbol{k}_{o} \& \boldsymbol{k}_{E u}$}

A series of $\left[\mathrm{Eu}^{3+}\right]$ perchlorate and triflate solutions was gathered and recorded at a wavelength of $614 \mathrm{~nm}$ at a low $\mathrm{pH}$ to eliminate hydrolysis. Figure 2 shows spectra of 
different $\mathrm{Eu}^{3+}$ concentrations at $\mathrm{pH}<5.0$. The spectra indicated that there was no peak shift with increasing $\left[\mathrm{Eu}^{3+}\right]$; as $\left[\mathrm{Eu}^{3+}\right]$ increased, the intensity increased at $614 \mathrm{~nm}$.

However, the luminescence was emitted at four different wavelengths: 590, 614, 649, and $695 \mathrm{~nm}$. These transition peaks occurred at energy level $J=1,2,3$, and 4, respectively. The emission intensity is formulated as:

\subsection{I $I=k_{o}+k_{E u}[E u]$}

where constant $k_{o}$ was the instrumental solvent constant, and constant $k_{E u}$ was the free europium constant.

As spectral results were collected at $\mathrm{pH}<5.0$, a linear plot of emission intensity as a function of $\left[\mathrm{Eu}^{3+}\right]$ at wavelength $614 \mathrm{~nm}$ was obtained. Figure 3 shows a linear regression with y-intercept $\left(k_{o}\right)=5.27 \times 10^{3}$ and the slope $\left(k_{E u}\right)=7.41 \times 10^{6}$, where constant $k_{E u}$ was the free europium constant. 


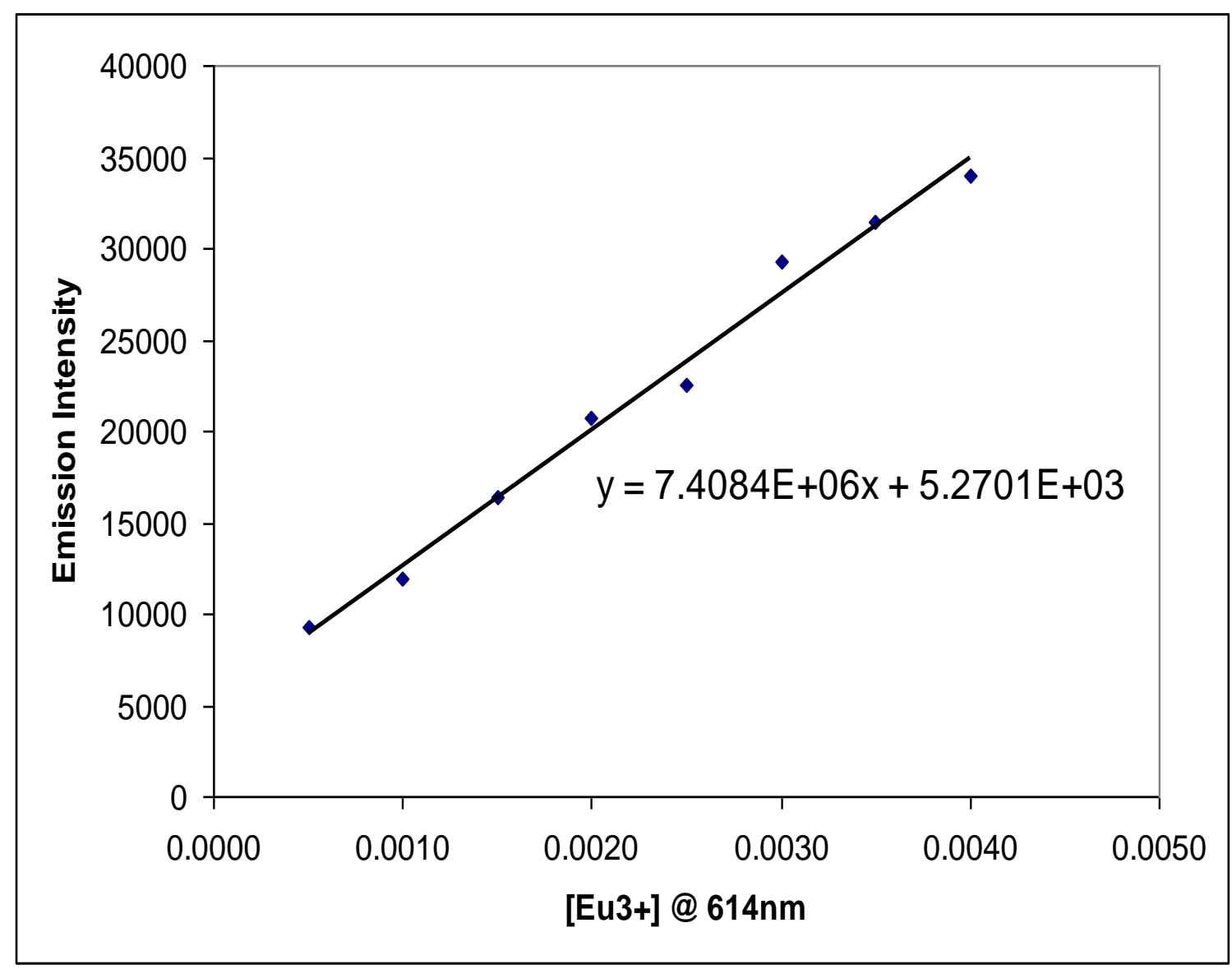

Figure 3. Linear regression line at low $\mathrm{pH}(\mathrm{pH}<5.0)$ of $\mathrm{Eu}(\text { trif })_{3}$ at wavelength of $614 \mathrm{~nm}$. 


\section{Determination of Constant $k_{L}$}

After free $\left[\mathrm{Eu}^{3+}\right]$ was characterized, the effects of adding D-glucosamine to $\left[\mathrm{Eu}^{3+}\right]$ below pH 5 were studied. Although small differences were observed at various concentrations, they were too small to measure constant $k_{E u L}$. During the first set of initial solutions, [D-glucosamine] was selected to record emission intensity at $\mathrm{pH}<5.0$. Figure 4 depicts a reaction of $\mathrm{Eu}(\mathrm{III})-\mathrm{D}$-glucosamine complex at $\mathrm{pH}<5.0$.

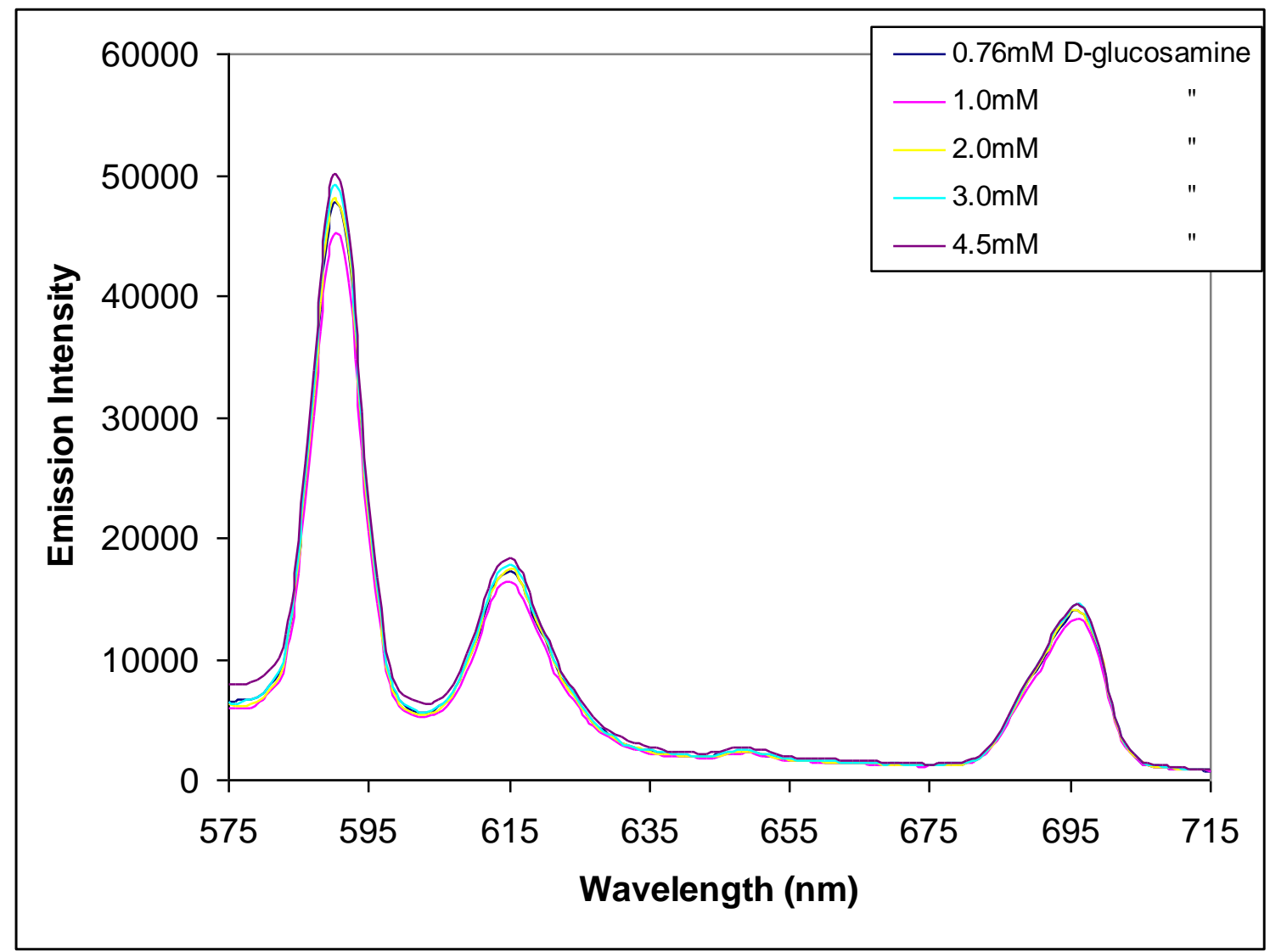

Figure 4. $\mathrm{Eu}(\mathrm{III})$ - D-glucosamine reaction at $\mathrm{pH}<5.0$ and at constant europium concentration. 
Wavelength at $614 \mathrm{~nm}$ (Figure 4) showed the transition peaks are slightly changed with increasing [D-glucosamine]. These results showed that [D-glucosamine] interacts with $\left[\mathrm{Eu}^{3+}\right]$ at a low $\mathrm{pH}$ indicating a weak complexation. Luminescence spectra illustrated Eu (III) - D-glucosamine reaction at energy level $J=2$ transition, and consequently, this transition obtained a higher intensity when the $\mathrm{pH}$ was raised. When [D-glucosamine] increases at a high $\mathrm{pH}$, peak intensity will increase accordingly (Figure $5)$.

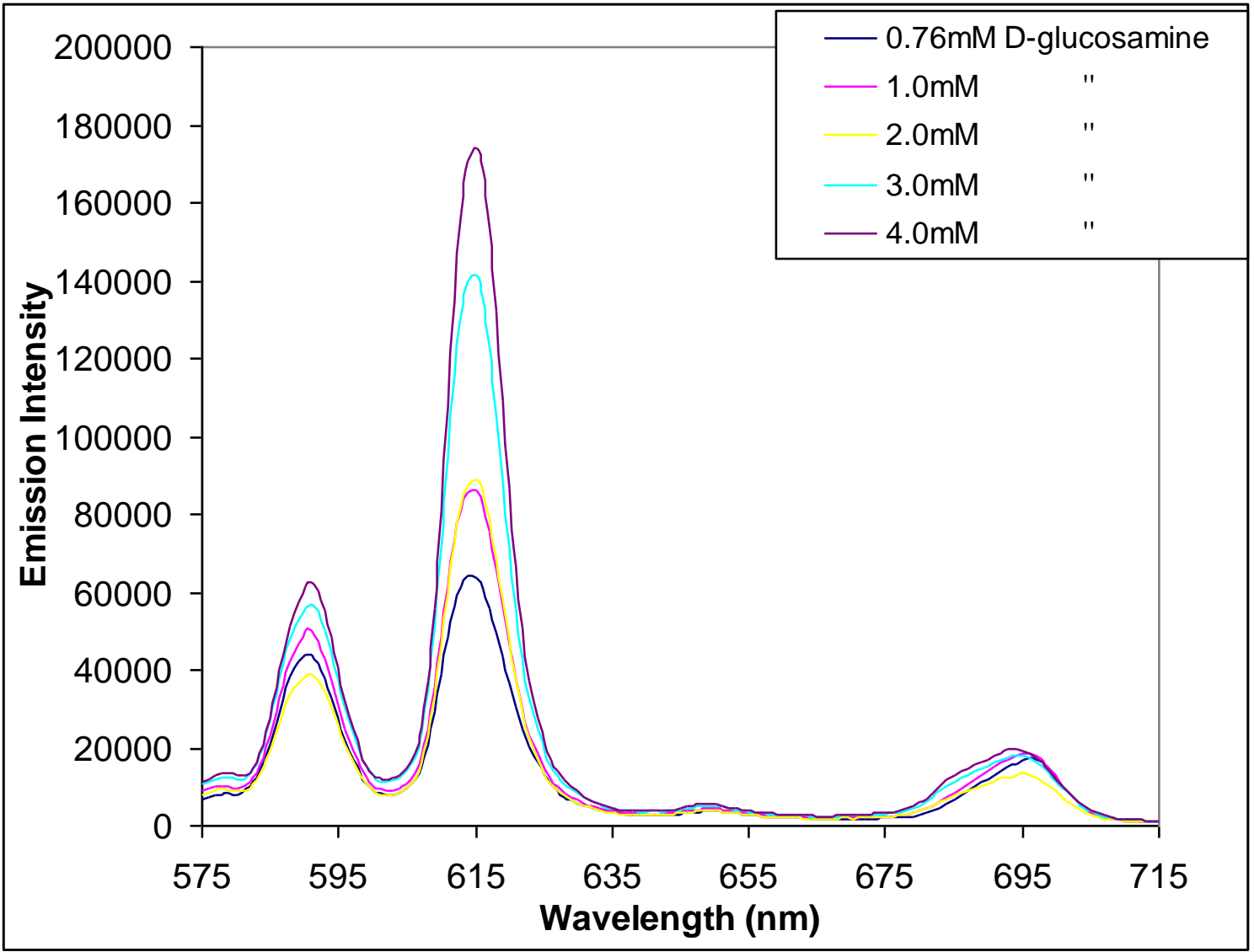

Figure 5. Luminescence spectra of Eu(III)-D-glucosamine complex at emission intensity as a function a wavelength at $\mathrm{pH} \sim 7.40$ and $25^{\circ} \mathrm{C}$. 
Additionally, when ligand was added to $\left[\mathrm{Eu}^{3+}\right]$ at $\mathrm{pH}<5$, the reaction was quantify. Figure 6 illustrates that constant $k_{E u L}$ at $\mathrm{pH}<5$ was very small compared to all other results.

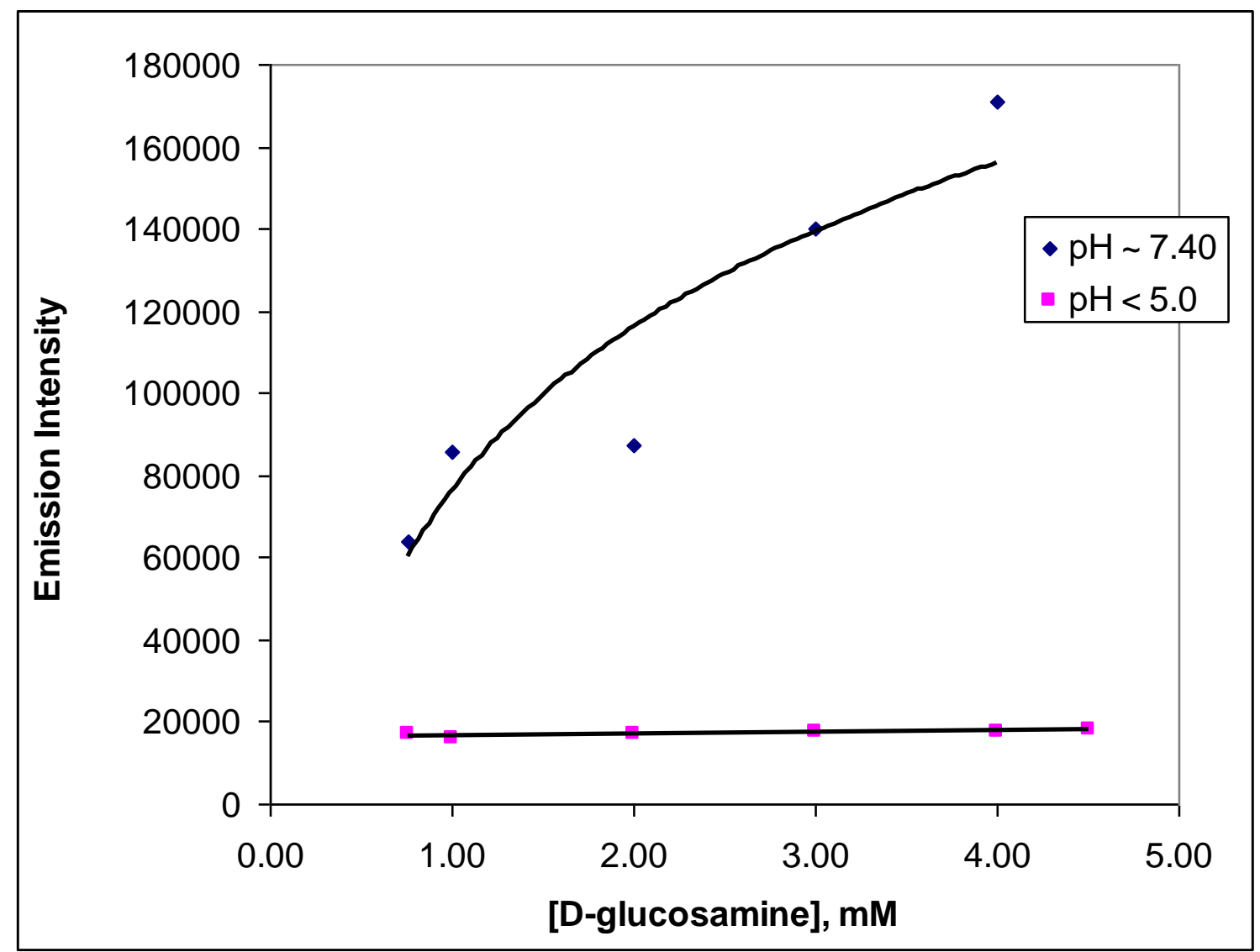

Figure 6. Emission intensity versus [D-glucosamine] at difference pH and at wavelength of $614 \mathrm{~nm}$. 


\section{Determination of Constant $k_{\mathrm{EuOH}}$}

A few data points of three other monosaccharide ligands were studied to measure the intensity. The experiments with the monosaccharide sugars galactose, mannose, and ribose (Table 3$)$ were conducted under the same temperature $\left(25^{\circ} \mathrm{C}\right)$ and $\mathrm{pH}$ conditions $(\mathrm{pH} \sim 7.40)$ as those used for D-glucosamine. Figure 7 shows four different monosaccharide ligand curves. Although the emission intensity of each sugar was different, the y-intercepts are similar.

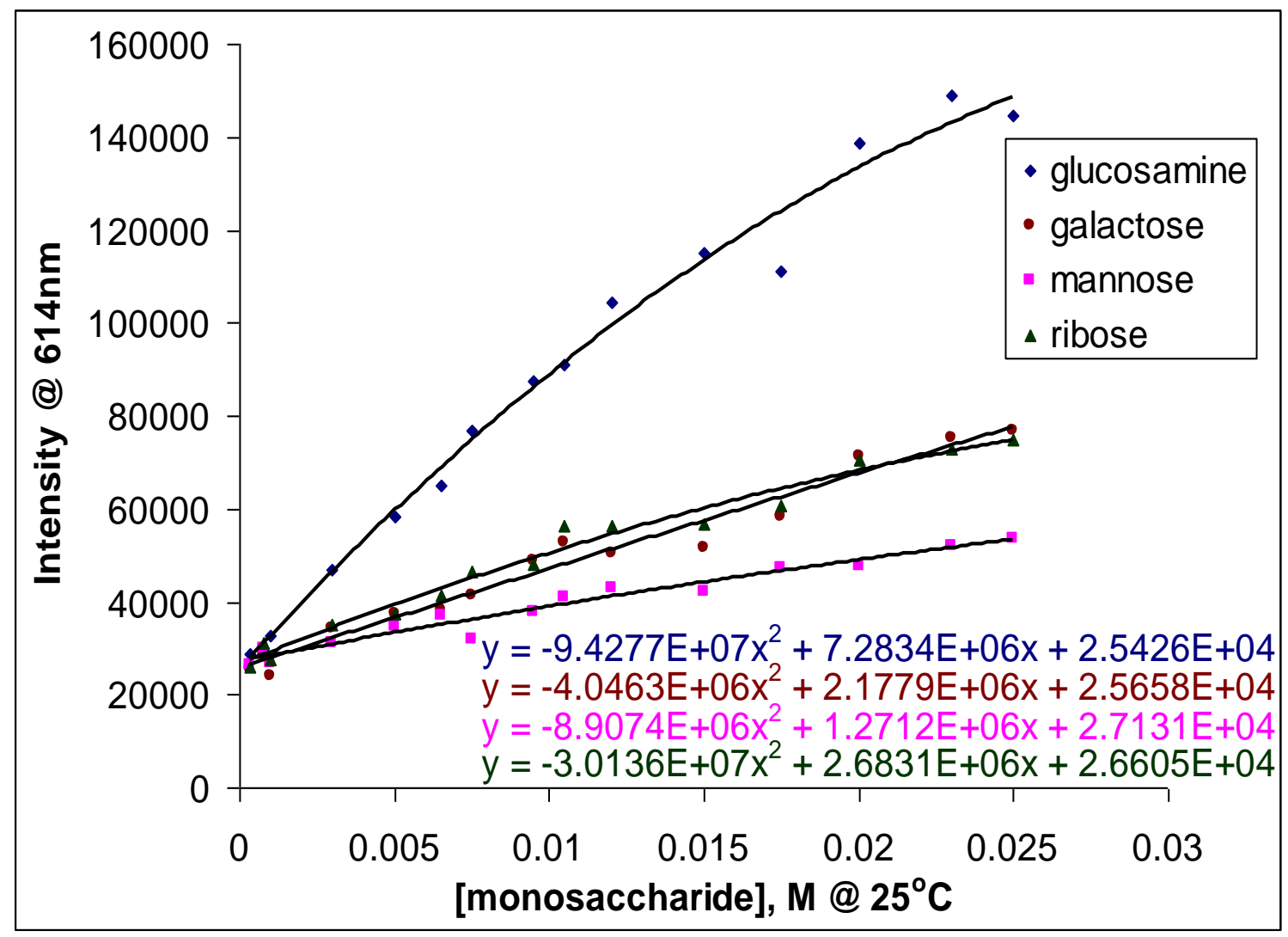

Figure 7. Observation of different monosaccharide ligands at $\mathbf{p H} \sim 7.40$. 
Intensities at intercept of the four sugars were similar. The average intensity at zero ligand concentration was calculated. The average intensity, $I_{o}$, of these monosaccharide ligands was determined to be $2.62 \times 10^{4}$. From this average intensity, constant $k_{E u O H}$ could be calculated. The intensity $\mathrm{I}_{\mathrm{o}}$ value is computed as:

\section{$3.2 \quad I_{o}=k_{o}+k_{E u}[E u]+k_{E u O H}[E u O H]$}

The constants $k_{o}$ and $k_{E u}$ have already been determined; therefore, if intensity $I_{o}$, $\left[\mathrm{Eu}^{3+}\right]$ and $\left[\mathrm{EuOH}^{2+}\right]$ were known, then constant $k_{E u O H}=1.18 \times 10^{7}$ could be calculated from Figure 8, where $I_{o}=2.62 \times 10^{4}, k_{o}=5.27 \times 10^{3}$ and $k_{E u}=7.41 \times 10^{6}$. When the hydrolysis equation was calculated, the free europium $[\mathrm{Eu}]$ and $[\mathrm{EuOH}]$ concentrations were obtained, $[\mathrm{Eu}]=1.12 \times 10^{-3} \mathrm{M}$ and $[\mathrm{EuOH}]=1.06_{6} \times 10^{-3} \mathrm{M}$. All of the calculations were described in the Appendix A. The average intensity calculated from the y-intercept was used to determine the value of the equilibrium constant, $K_{E u L}$.

The equilibrium constant $K_{E u L}$ of each europium ligand complex was calculated based on the collected data shown in Figure 7. However, steps of calculations for the three ligands were similar to that of D-glucosamine calculations. Table 4 below shows an equilibrium constant, $K_{E u L}$ and intercept intensity for each monosaccharide ligand. The equilibrium constants for the monosaccharide sugars are smaller than the constant for the D-glucosamine ligand.

Table 4: Equilibrium Constant, $K_{E u L}$, of Each Monosaccharide Ligand

\begin{tabular}{|l|c|c|}
\hline Ligand & $\mathbf{K}_{\mathbf{E u L}}=[\mathbf{E u L}] /([\mathbf{E u}] \mathbf{x}[\mathbf{L}])$ & Intensity at y-intercept \\
\hline Galactose & 6.35 & $2.56 \times 10^{4}$ \\
\hline Mannose & 5.35 & $2.71 \times 10^{4}$ \\
\hline Ribose & 13.32 & $2.66 \times 10^{4}$ \\
\hline
\end{tabular}




\section{Determination of the Absence of EuOHL}

Before calculating constants $k_{E u L}$ and $k_{E u O H L}($ Equation 2.3), the species that were present at $\mathrm{pH} \sim 7.40$ would be evaluate using FTIR and excitation measurements.

\section{a. FTIR Measurements}

FTIR spectra was used to determine the functional groups of the $\mathrm{Eu}(\mathrm{III})-$

D-glucosamine complex at $\mathrm{pH} \sim 7.40$. FTIR of the Eu(trif $)_{3}-\mathrm{D}$-glucosamine appeared to be a perfect sum of the Eu(trif) $)_{3}$ and D-glucosamine spectra. As shown in Figure 8, three stretching bands from the functional groups $\mathrm{CO}_{2}, \mathrm{NH}$, and $\mathrm{C}=\mathrm{O}$ from $\mathrm{Eu}(\text { trif })_{3}$ were observed.

Triflic (trifluoromethanesulfonic) acid contained carbon, fluorine, sulfur, oxygen, and hydrogen. The small band at $1034 \mathrm{~cm}^{-1}$ was assigned to a $\mathrm{C}-\mathrm{F}$ stretch. The strong sharp band located next to $\mathrm{C}-\mathrm{F}$ band at $1257 \mathrm{~cm}^{-1}$ was assigned to the $\mathrm{S}=\mathrm{O}$ stretch. A medium bandwidth at $2345 \mathrm{~cm}^{-1}$ indicated an $\mathrm{S}-\mathrm{OH}$ stretch from triflic acid. The three bands provided evidence for the presence of trifluoromethanesulfonic acid. Thus, Eu band located at $570.82 \mathrm{~cm}^{-1}$. 


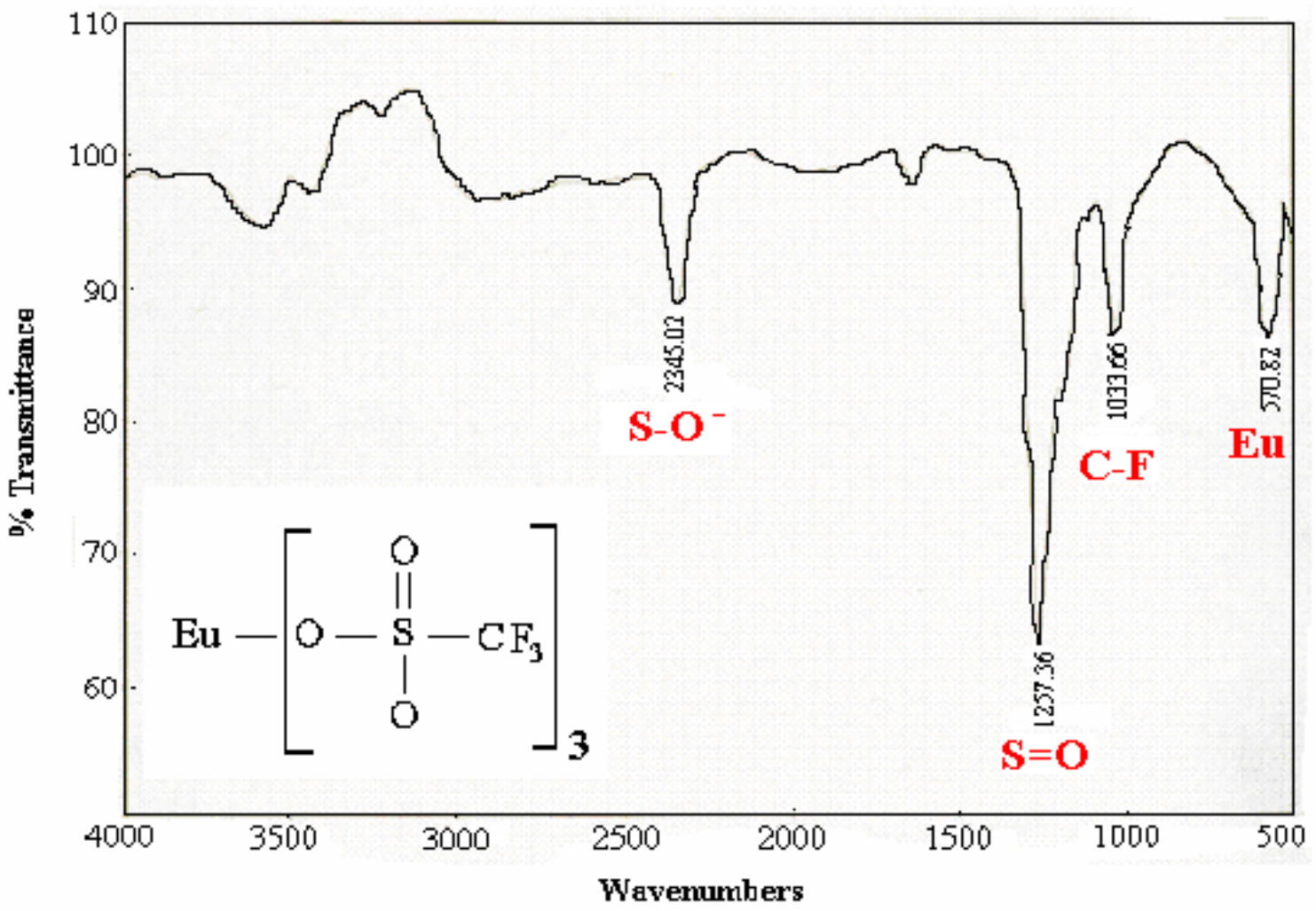

Figure 8. FTIR spectrum shows a $0.100 \mathrm{M}$ Eu(trif $)_{3}$ at $\mathbf{p H} \sim 7.40$. 
The FTIR spectrum of a free D-glucosamine indicated two main bands (Figure 9). Since D-glucosamine had four hydroxyl $(\mathrm{OH})$ groups attached to the cyclic pyranose ring, a strong $\mathrm{OH}$ band appeared at $3420 \mathrm{~cm}^{-1}$. The medium band at $1641 \mathrm{~cm}^{-1}$ indicated a C-NH stretch.

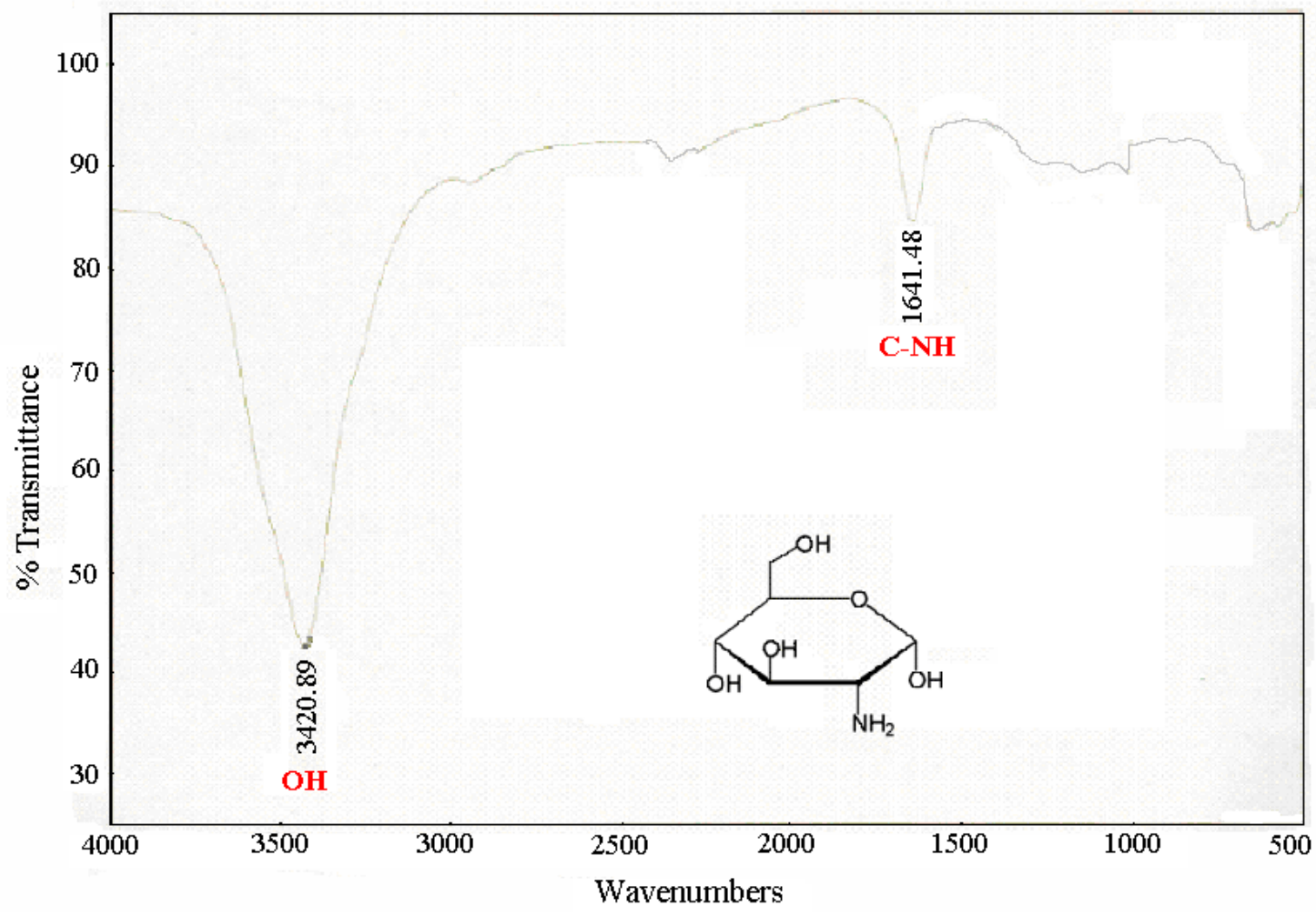

Figure 9. FTIR spectrum shows a $0.100 \mathrm{M}$ D-glucosamine at pH $\sim 7.40$. 
Figure 10 shows the FTIR spectrum of D-glucosamine and $\mathrm{Eu}(\text { trif })_{3}$ at a 1:1 molar ratio. A strong $\mathrm{OH}$ band appearing at $3423 \mathrm{~cm}^{-1}$ confirmed the presence of free water. Another strong and sharp band observed at $1250 \mathrm{~cm}^{-1}$ represented a $\mathrm{S}=\mathrm{O}$ bond stretching from $\mathrm{Eu}(\text { trif })_{3}$. Two other medium sharp bands at $2345 \mathrm{~cm}^{-1}$ and $1054 \mathrm{~cm}^{-1}$ confirmed a $\mathrm{S}-\mathrm{OH}$ and a C-F bond from the $\mathrm{Eu}\left(\right.$ trif $_{3}$ solution, respectively. Since europium (Eu) is a heavy metal, its transmittance corresponded to a lower frequency of $633 \mathrm{~cm}^{-1}$. Atoms coordinated to Eu also share lower frequencies of vibration. Shifted bands confirmed there was a complex interaction between D-glucosamine and $\mathrm{Eu}(\text { trif })_{3}$.

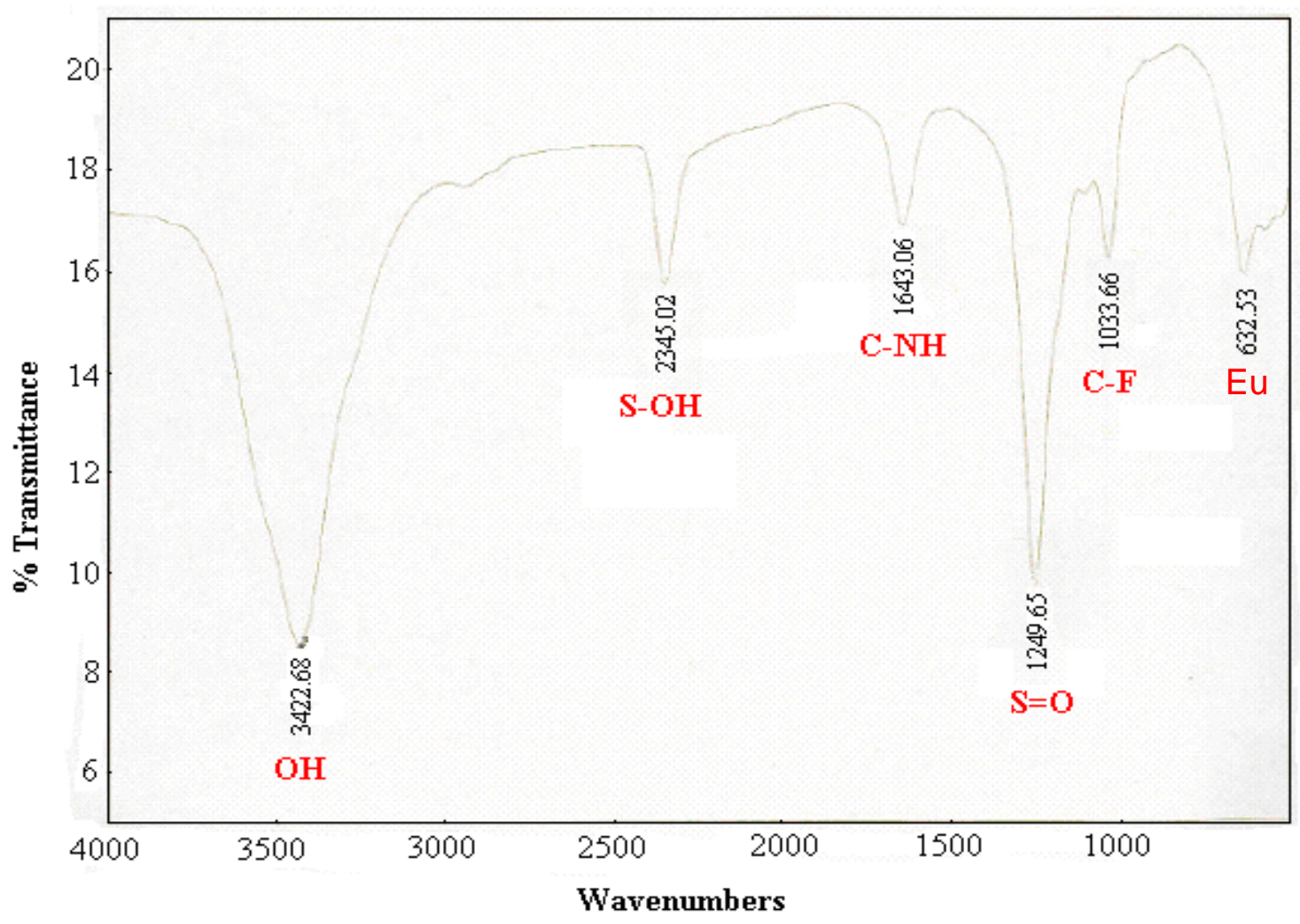

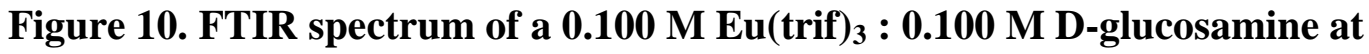
pH $~ 7.40$. 
The FTIR spectrum shown in Figure 10 indicated two functional groups (Eu and $\mathrm{S}=\mathrm{O}$ ) that shifted when the ligand D-glucosamine was added to the europium-triflic solution. The europium (Eu) band shifted from $571 \mathrm{~cm}^{-1}$ (Figure 7) to $633 \mathrm{~cm}^{-1}$ (Figure 10). The $\mathrm{S}=\mathrm{O}$ band indicated a small shift from wavenumber $1257 \mathrm{~cm}^{-1}$ (Figure 7) to $1250 \mathrm{~cm}^{-1}$ (Figure 10). These band shifts were consistent with complexation but indicated a stronger interaction between triflate and $\mathrm{Eu}(\mathrm{III})$ than between D-glucosamine and Eu(III).

\section{b. Excitation Measurements}

Excitation spectroscopy was used to determine whether $\mathrm{Eu}^{3+}$ or $\mathrm{EuOH}^{2+}$ binds to D-glucosamine. When free europium $\left(\mathrm{Eu}(\text { trif })_{3}\right)$ in $\mathrm{NaClO}_{4}$ solution at $\mathrm{pH} \sim 7.40$ was measured under the dye laser excitation at $617.5 \mathrm{~nm}$, a single peak appeared at wavelength $578.7 \mathrm{~nm}$ (Figure 11). Another single peak was observed at $578.5 \mathrm{~nm}$ for $\mathrm{Eu}(\mathrm{III})$ triflate in the absence of $\mathrm{NaClO}_{4}$ solution (Figure 11). These spectral results indicated that the $\mathrm{NaClO}_{4}$ solution had little or no effect on the intensity. If $\mathrm{EuOH}^{2+}$ was present in the sample, a shoulder peak would be expected to appear next to the $\mathrm{Eu}^{3+}$ peak. However, no shoulder peak was visible in the spectrum. Therefore only free europium ion $\left(\mathrm{Eu}^{3+}\right)$ was detected in this solution. 


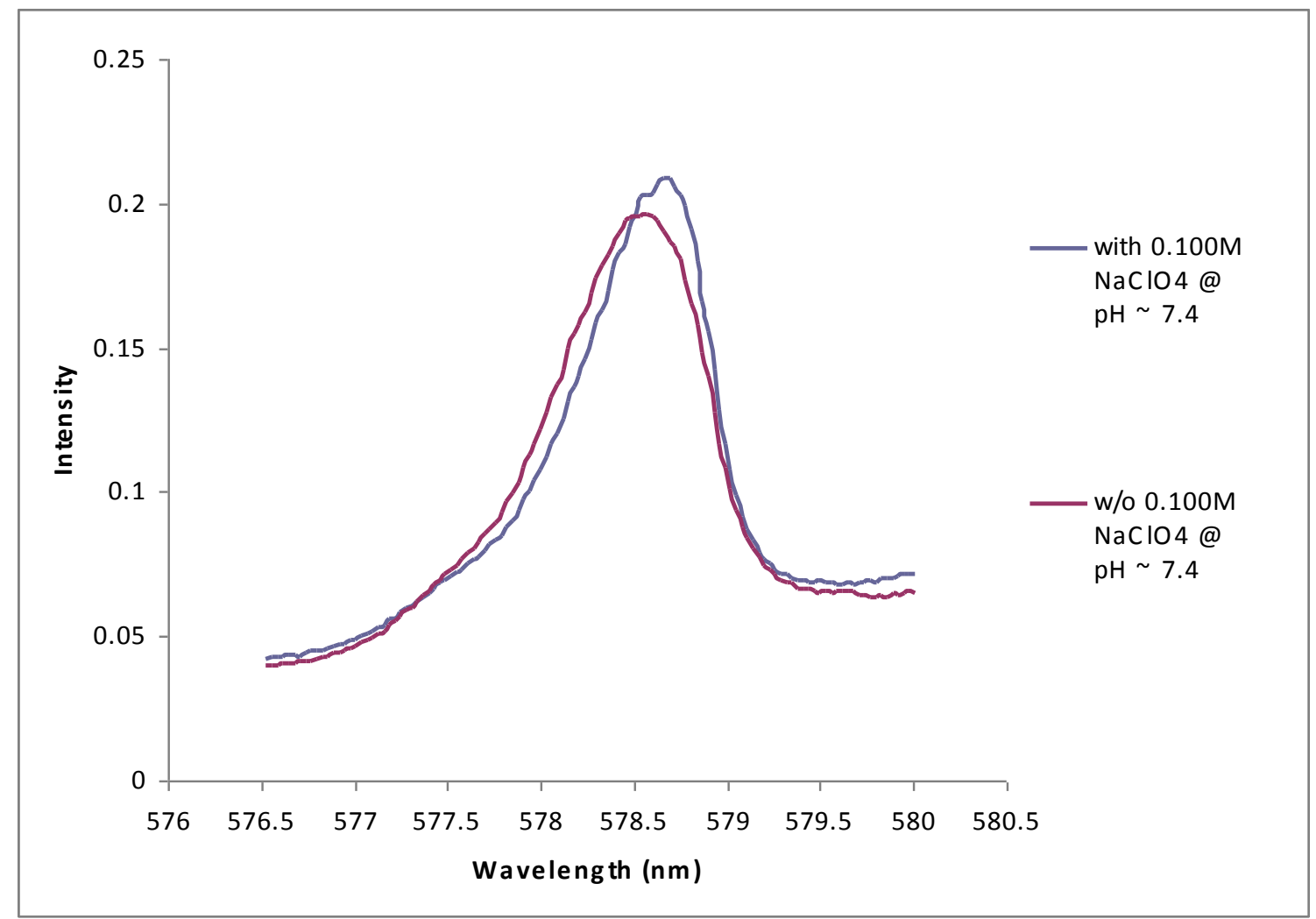

Figure 11. Excitation measurements of $0.100 \mathrm{M} \operatorname{Eu}(\text { trif })_{3}$ with and without $0.100 \mathrm{M}$ $\mathrm{NaClO}_{4}$ at $\mathrm{pH} \sim 7.40$.

When D-glucosamine solution was added to free europium and $\mathrm{NaClO}_{4}$ solution at $\mathrm{pH} \sim 7.40$, the excitation spectrum exhibited two peaks (Figure 12). 


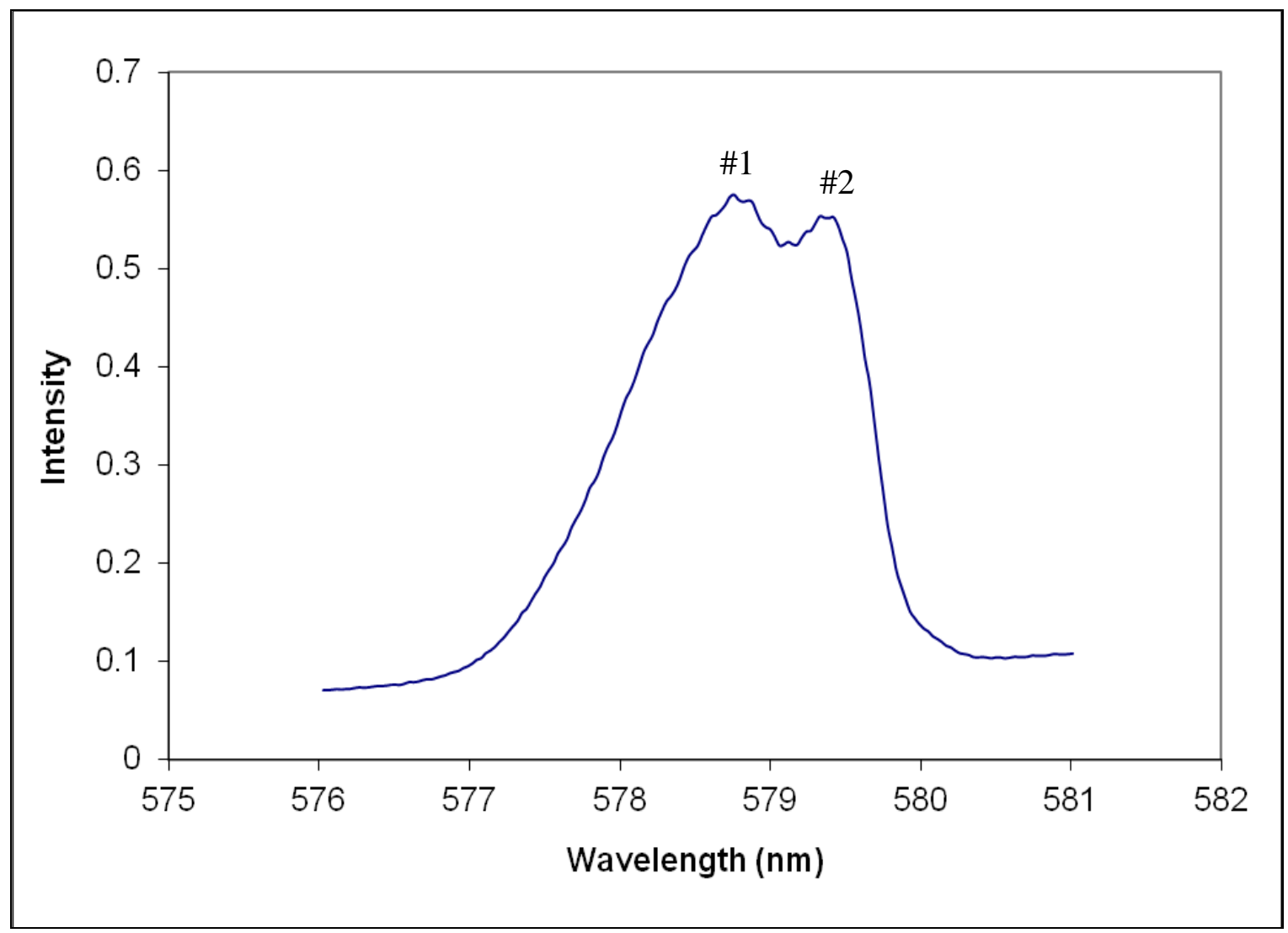

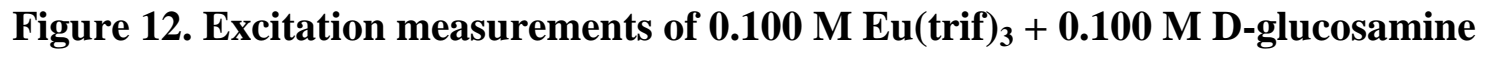
with $0.100 \mathrm{M} \mathrm{NaClO}_{4}$ at $\mathrm{pH} \sim 7.40$.

No precipitate was formed in the solution while intensity was being measured. However, after several minutes of letting the solutions to settle down, a precipitate was observed. The precipitate indicated that $\mathrm{Eu}(\mathrm{OH})_{2}$ may be forming. Peak \#1 appeared at $578.8 \mathrm{~nm}$, and peak \# 2 appeared at $579.4 \mathrm{~nm}$ (Figure 12) that Eu(III) and D-glucosamine were present at $\mathrm{pH} \sim 7.40$. Since the peak at $578.8 \mathrm{~nm}$ appeared in water at $\mathrm{pH} \sim 7.40$, the peak at $579.4 \mathrm{~nm}$ was assigned to the D-glucosamine complex. Since no additional peak was observed that might indicate $\mathrm{EuOH}^{2+}$ binding, it can be concluded that $\left(\mathrm{Eu}^{3+}\right)$ bound to the $\mathrm{D}$-glucosamine ligand at $\mathrm{pH} \sim 7.40$. 
According to the data presented by Hedinger, et al., (1998), europium

complexation ( $\mathrm{Eu}(\mathrm{III})$ - D-glucosamine) appeared to occur at a $\mathrm{pH}$ between 7 and 9, and significant $\mathrm{EuOH}^{2+}$ complexation occured at $\mathrm{pH}$ above 9. The deprotonation of the hydroxo complex appeared at pH above 9 (Hedinger, et al., 1998).

\section{Determination of Equilibrium Constant $K_{E u L} \&$ Constant $k_{E u L}$}

A series of spectra with D-glucosamine concentrations were shown at $\mathrm{pH} \sim 7.40$ (Figure 13).

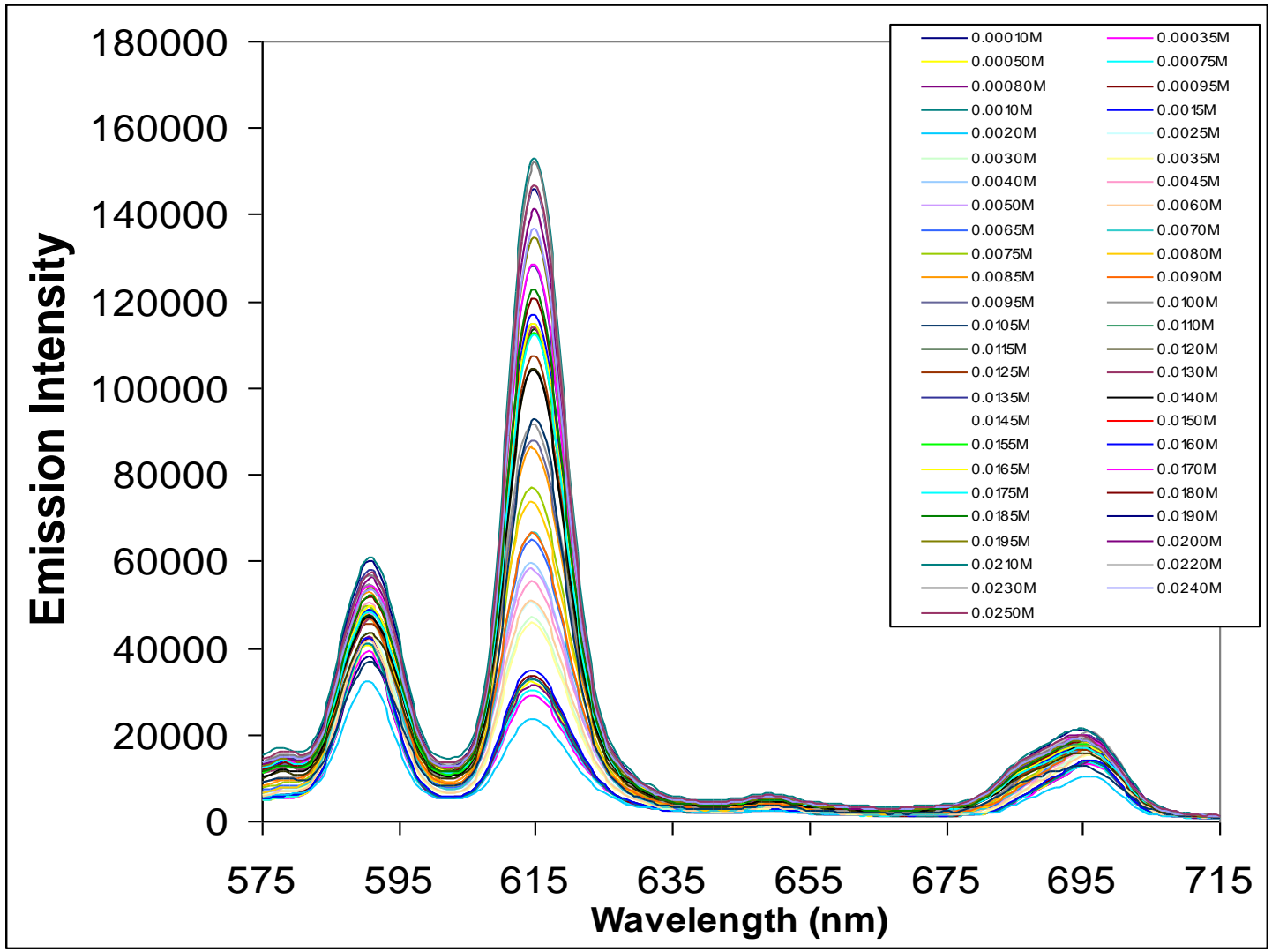

Figure 13. Luminescence spectra of $\mathrm{Eu}(\mathrm{III})$ - D-glucosamine excitation at wavelength $318 \mathrm{~nm}, \mathrm{pH} \sim 7.40$. 
Figure 13 and Figure 14 illustrated a polynomial function that models a reaction between $\mathrm{Eu}(\mathrm{III})$ and D-glucosamine.

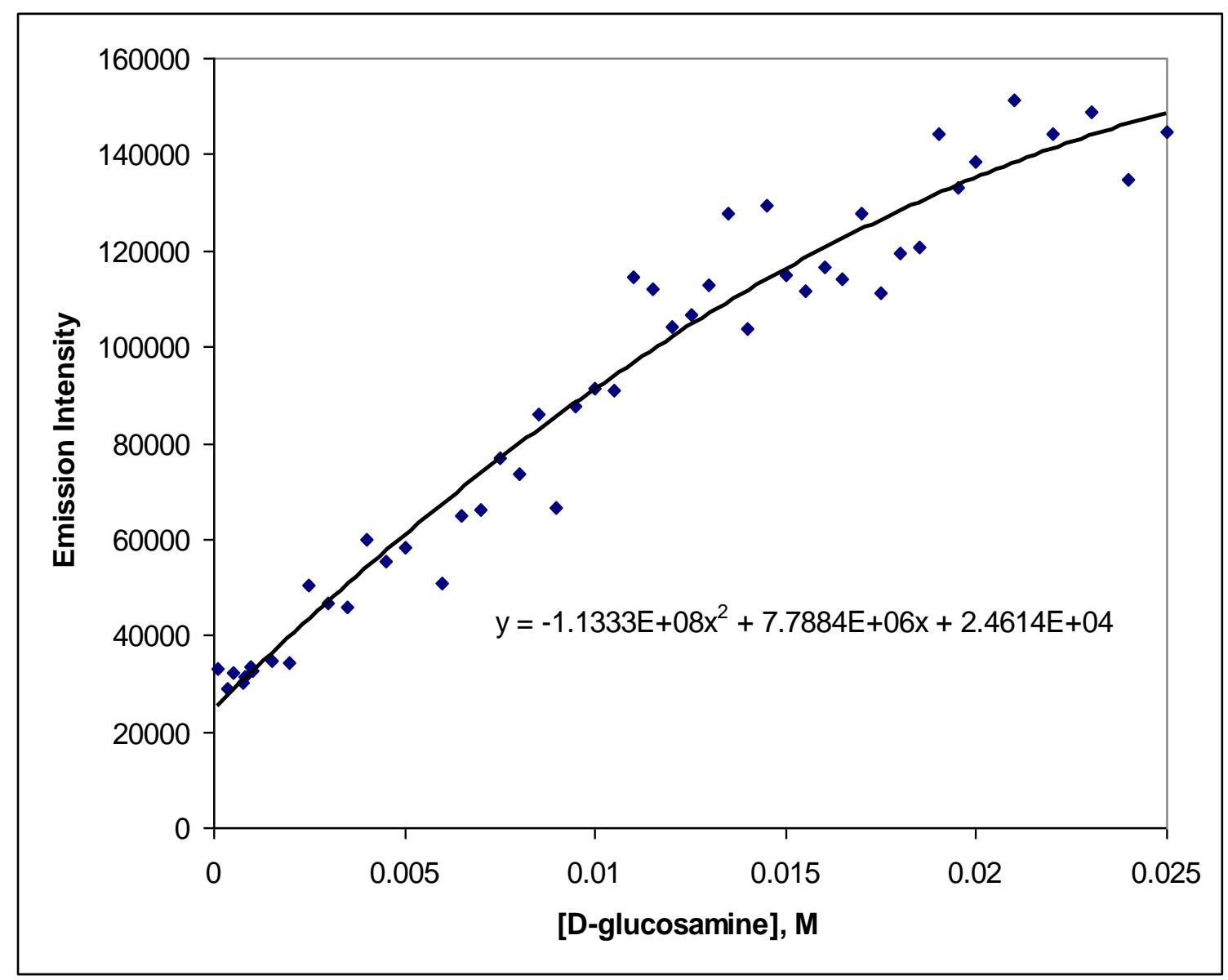

Figure 14. An $\mathrm{Eu}(\mathrm{III})$ - D-glucsosamine curve function at $\mathrm{pH} \sim 7.40$ and wavelength of $614 \mathrm{~nm}$ at $[\mathrm{Eu}]_{\mathrm{t}}=2.50 \times 10^{-3} \mathrm{M}$. 
When constants $k_{L}$ and $k_{E u O H L}$ were omitted from emission intensity

measurements at $\mathrm{pH} \sim 7.40$ (Equation 2.3), the response may be expressed as:

\section{3 $\quad I_{o}=k_{o}+k_{E u}[E u]+k_{E u O H}[E u O H]+k_{E u L}[E u L]$}

As the value of each physical term from Equation 3.3 has been determined, the initial emission intensity, $I_{o}$, value was equal to the sum of each of the above terms. At low $\mathrm{pH}$, the constants $k_{o}$ and $k_{E u}$ were found to be $k_{o}=5.27 \times 10^{3}$ and constant $k_{E u}=7.41 \times 10^{6}$, respectively. The free europium concentration value was calculated $\left([\mathrm{Eu}]=1.12 \times 10^{-3} \mathrm{M}\right)$, as described in the Appendix A. The europium hydroxide concentration was calculated $\left([\mathrm{EuOH}]=1.07 \times 10^{-3} \mathrm{M}\right)$ from the hydrolysis reaction as described in the Appendix A using Equation 1.4. The value of constant $k_{E u O H}$ was finally calculated from Equation 3.2, yielding a value of $1.18 \times 10^{7}$. The emission intensity, $I_{o}=2.46 \times 10^{4}$ was calculated from the polynomial in Figure 14.

The calculated intensity ( $\left.I^{\prime}\right)$ is computed as:

$$
\text { 3.4 I' }=I-k_{o}-k_{E u}[E u]-k_{E u O H}[E u O H]=k_{E u L}[E u L]
$$

where constant $\mathrm{k}_{\mathrm{o}}$ and constant $\mathrm{k}_{\mathrm{Eu}}$ were determined from the measurements of free europium at low $\mathrm{pH}$. The determination of constant $\mathrm{k}_{\mathrm{EuOH}}$ was calculated based on Equation 3.2. The calculated intensity ( $\left.I^{\prime}\right)$ was equal to constant $k_{E u L}[\mathrm{EuL}]$. Therefore, constant $k_{E u L}$ was formulated as: 
$3.5 \quad \mathrm{k}_{\mathrm{EuL}}=\frac{\mathrm{I}-\mathrm{k}_{\mathrm{o}}-\mathrm{k}_{\mathrm{Eu}}[\mathrm{Eu}]-\mathrm{k}_{\mathrm{EuOH}}[\mathrm{EuOH}]}{[\mathrm{EuL}]}$

The equilibrium constant $K_{E u L}$ was computed by dividing the product by the reactants as shown in Equation 2.5 and 3.7. A full description of the calculations for $[\mathrm{Eu}],[\mathrm{EuL}]$, and $[\mathrm{EuOH}]$ is shown in the Appendix A. However, in order to calculate [EuL], an estimated value for the equilibrium constant $K_{E u L}$ was used. When the estimated equilibrium constant $K_{E u L}$ value was obtained, the concentration of Eu and the concentration of EuL were calculated using the equation in Appendix A.

The complexation reaction was written as the equilibrium:

\section{6 $\mathrm{Eu}(\mathrm{III})+\mathrm{D}$-glucosamine $\longleftrightarrow \mathrm{Eu}(\mathrm{III})-\mathrm{D}$-glucosamine}

Thus the equilibrium constant, $K_{E u L}$, was simplified to:

$3.7 \quad \mathrm{~K}_{\mathrm{EuL}}=\frac{[\mathrm{Eu}(\mathrm{II})-\mathrm{D} \text {-glucosamine }]}{[\mathrm{Eu}(\mathrm{II})] \times[\mathrm{D} \text {-glucosamine }]}$

The calculated equilibrium constant $K_{E u L}$ was determined using a Microsoft Excel spreadsheet based on the calculated total europium and total D-glucosamine concentrations. Equation 1.7 was also rearranged to give a determinant equation:

\section{$3.8 I-k_{0}-k_{E u}[E u]-k_{E u O H}[E u O H]=k_{E u L}[E u L]$}


Equation 3.8 was a straight line with a zero intercept. Once the constant $k_{E u O H}$ was determined, an estimated value of equilibrium constant $K_{E u L}$ was obtained. Calculations were performed for free complexed europium and free D-glucosamine. The plotted graph $I-k_{0}-k_{E u}[\mathrm{Eu}]-k_{E и O H}[\mathrm{EuOH}]$ versus $k_{\mathrm{EuL}}[\mathrm{EuL}]$ determined the linear regression line. If the estimated value of equilibrium constant $K_{E u L}$ was high, the result was a negative intercept, as shown in Figure 15a.

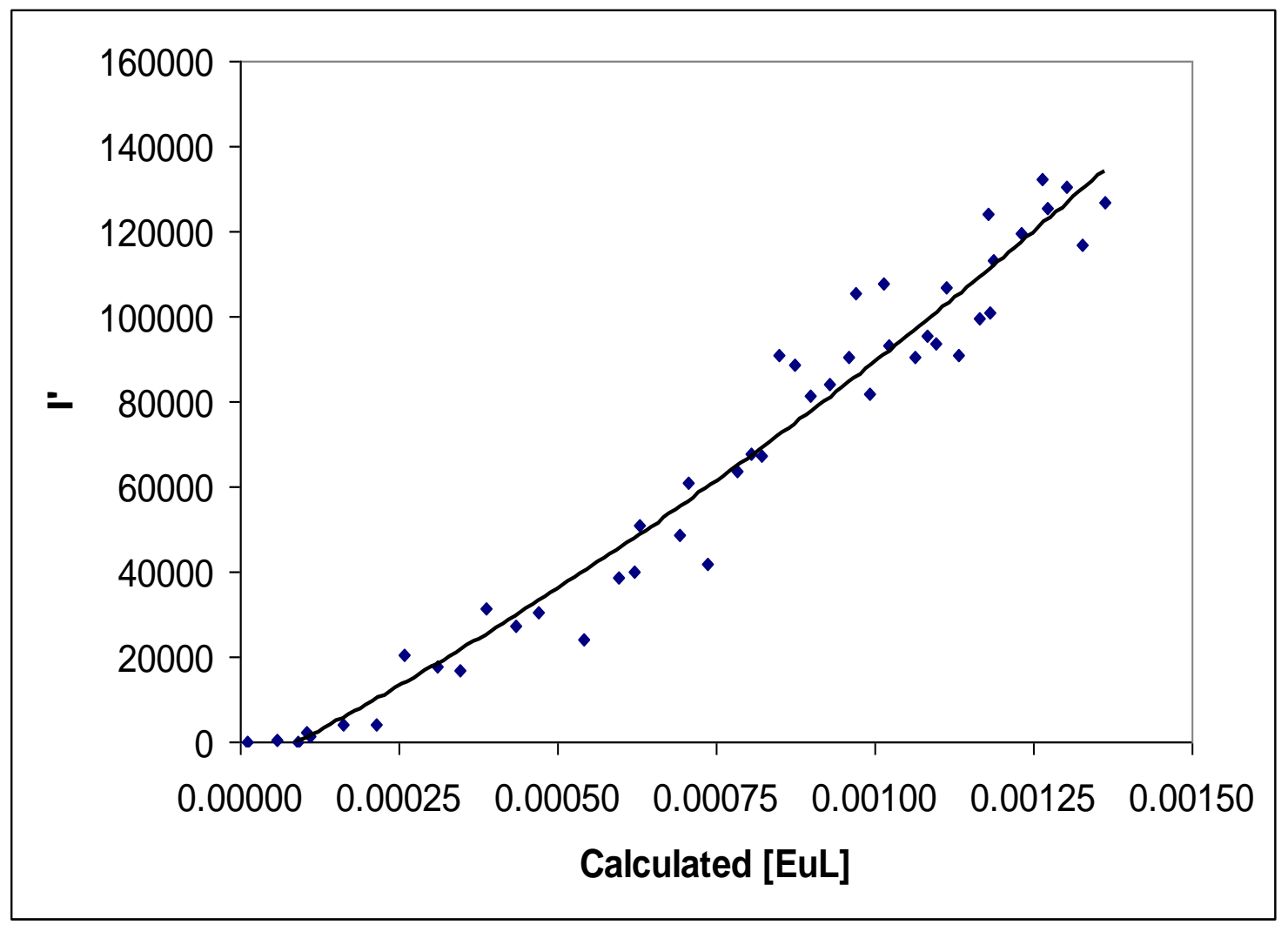

Figure 15a. A calculated intensity $\left(I^{\prime}\right)$ as a function of [EuL] $(\mathrm{Eu}(\mathrm{III})$ D-glucosamine) when equilibrium constant $K_{E u L}$ is assumed to be 100 . 
However, if the equilibrium constant $K_{E u L}$ was low, then the result was a positive intercept, as shown in Figure 15b.

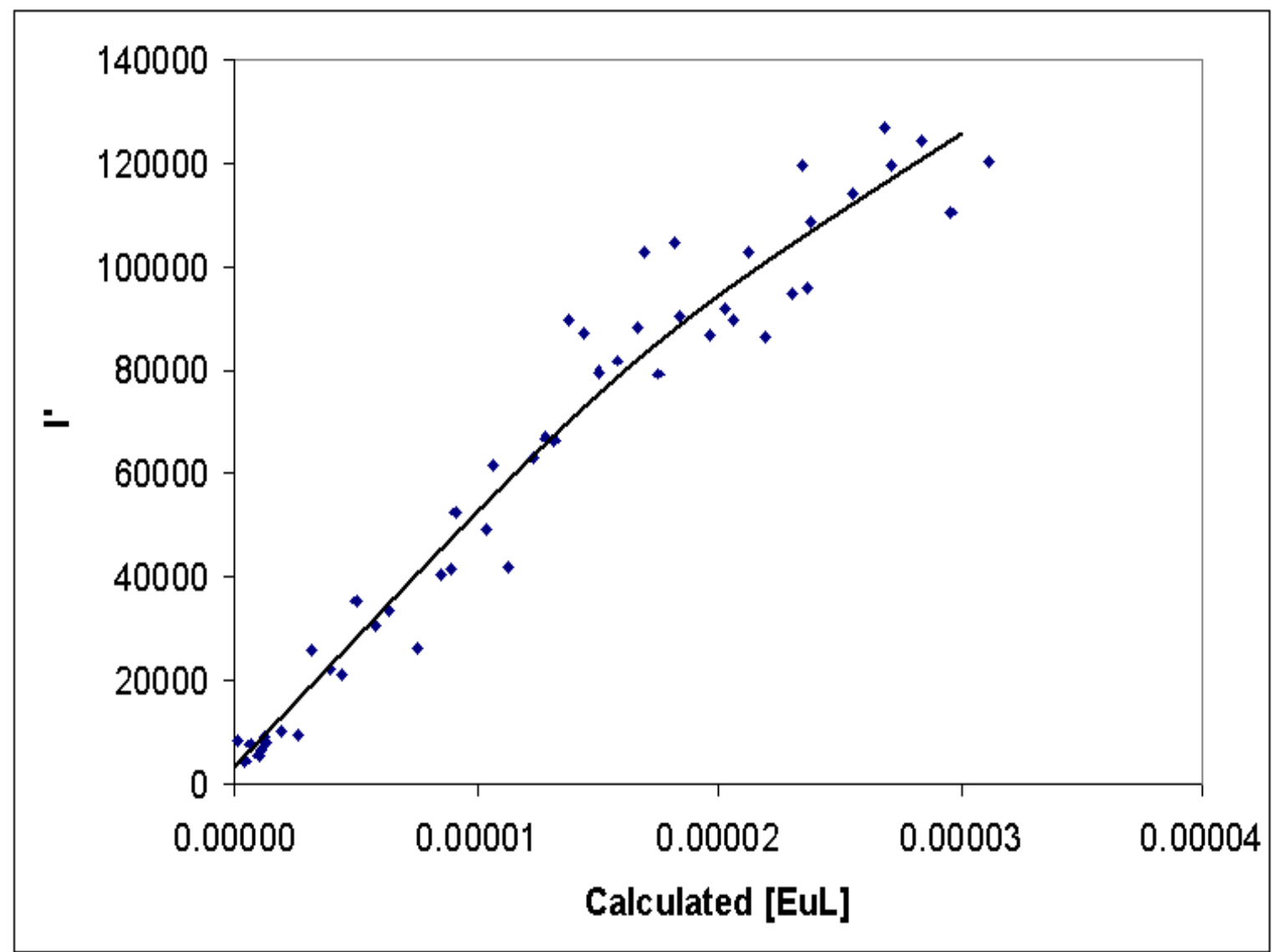

Figure 15b. A calculated intensity (I') as a function of [EuL] (Eu(III) D-glucosamine) when equilibrium constant $K_{E u L}$ is assumed to be 1 . 
When the best value of equilibrium constant was estimated, a good correlation between experimental data and the best straight line was an intercept at zero. The graph of the calculated intercept as a function of equilibrium constant $K_{E u L}$ was a curve that intersects at zero. The best equilibrium constant $K_{E u L}$ value was determined (Figure 15c).

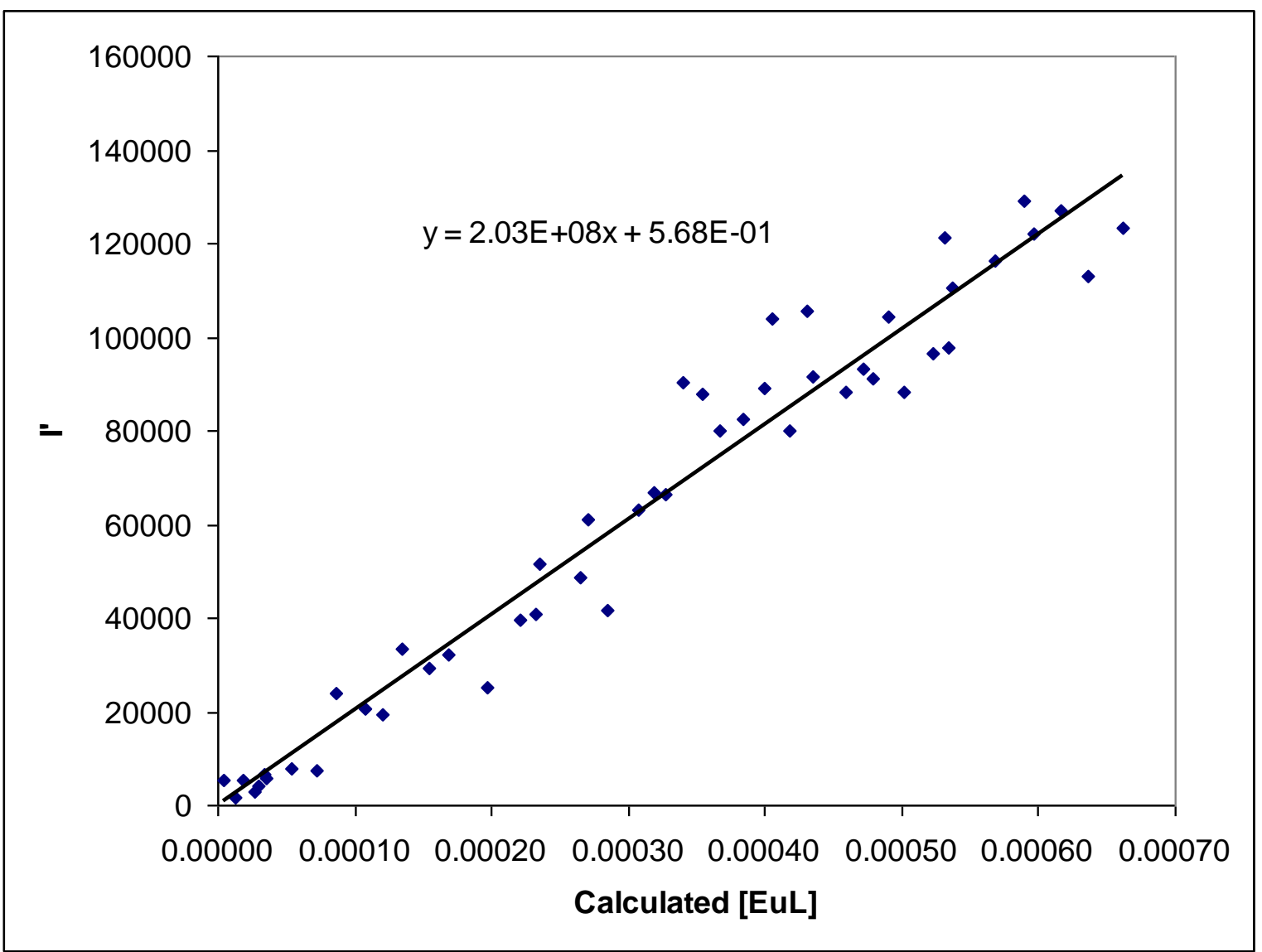

Figure 15c. A calculated intensity $\left(I^{\prime}\right)$ as a function of $[\mathrm{EuL}](\mathrm{Eu}(\mathrm{III})-$ D-glucosamine) when equilibrium constant $K_{E u L}$ is 29.24 , the best fit of the data at $25^{\circ} \mathrm{C}$. 


\section{Chapter 4}

\section{Conclusion}

The two main goals of this research were the determination of the equilibrium constant $K_{E u L}$ and identification of complex formation at $\mathrm{pH} \sim 7.40$ and $25{ }^{\circ} \mathrm{C}$. The hypersensitive emission peak at $614 \mathrm{~nm}$ was studied and indicated a complex reaction at $\mathrm{pH} \sim 7.40$. An increase of the D-glucosamine concentration resulted in an increase of the emission intensity at this wavelength. An equilibrium constant $K_{E u L}$ of the $\mathrm{Eu}(\mathrm{III})-$ D-glucosamine complex was found to be 29.24 .

Functional groups of D-glucosamine and $\mathrm{Eu}(\mathrm{III})$ were successfully observed in a solution-phase of the FTIR experiment. Laser excitation spectroscopy was used to determine if $\mathrm{D}$-glucosamine bound to europium ion $\left(\mathrm{Eu}^{3+}\right)$, or bound to the europium hydroxide ion $\left(\mathrm{EuOH}^{2+}\right)$. Therefore, evidence concludes that [Eu(III)]:[D-glucosamine]

complex indicated D-glucosamine bound to $\mathrm{Eu}^{3+}$ at $\mathrm{pH} \sim 7.40$, but there was no evidence that the complexation bound to hydrolyzed Eu (III) .

\section{Future Studies}

The results obtained here provide insights into the binding reaction and suggested further studies on temperature dependence of Eu binding with different monosaccharide ligands. Equilibrium constants $K_{E u L}$ can be determined at different temperatures under $\mathrm{pH} \sim 7.40$. 


\section{References}

Albin, M., Whittle, R. R., \& Horrocks, W. Jr. (1985). Laser spectroscopic and Xray structural investigation of europium (III)-oxydiacetate complexes in solution and in the solid state. Inorganic Chemistry, 24(26), 4591-4594.

Alekseev, Y. E., Garnovskii, A. D. \& Zhdanov, Y. A. (1998). Complexes of natural carbohydrates with metal cations. Russian Chemical Reviews, 67(8), 649-669.

Alptürk, O., Rusin, O., Fakayode, S. O., Wang, W., Escobedo, J. O., Warner, I. M., Crowe, W. E., Král, V., Pruet, J. M., \& Strongin, R. M. (2006). Lanthanide complexes as fluorescent indicators for neutral sugars and cancer biomarkers PNAS, 103(26), 9756-9760.

Atkinson, P., Bretonniere, Y., Parker, D., \& Muller, G. (2005). NMR and luminescence binding studies of ytterbium, thulium, and europium macrocyclic complexes with phosphorus (V) oxy anions. Helvetica Chimica Acta, 88(3), 391-405.

Bentouhami, E., Bouet, G. M., Meullemeestre, J., Vierling, F., \& Khan, M. A. (2004). Physicochemical study of the hydrolysis of rare-earth elements (III) and thorium (IV). Comptes Renduschimie, 7(5), 537-545.

Bucella, S., Riello, P., Scremin, B. F., Calvelli, P., Polloni, R., Speghini, A., Bettinelli, M., \& Benedetti, A. (2004). Synthesis and luminescence properties of $\mathrm{ZrO}_{2}$ and $\mathrm{ZrO}_{2} / \mathrm{SiO}_{2}$ composites incorporating $\mathrm{Eu}(\mathrm{III})$-phenanthroline complex prepared by a catalyst-free sol-gel process. Optical Materials, 27, 249-255.

Diáz, M. D. \& Berger, S. (2000). Studies of the complexation of sugars by diffusionordered NMR spectroscopy. Carbohydrate Research, 329(1), 1-5.

Hamilton, K. (August, 2003). Synthesis, characterization, and application of watersoluble chiral calix[4]arene derivatives in spectroscopy and capillary electrokinetic chromatography. Ph.D. Thesis, Louisiana State University and Agricultural and Mechanical College, Baton Rouge, LA.

Hedinger, R., Ghisletta, M., Hegetschweiler, K., Tóth, E., Merbach, E. A., Sessoli, R., Gatteschi, D., \& Gramlich, V. (1998). Trinuclear lanthanoid complexes of 1,3,5triamino-1,3,5-trideoxy-cis-inositol with a unique, sandwich-type cage structure. Inorganic Chemistry, 37, 6698-6705.

Jiménez-Reyes, M., Solache-Ríos, M., \& Rojas-Hernández, A. (2006). Application of the specific ion interaction theory $\rightarrow$ the solubility product and first hydrolysis constant of europium. Journal of Solution Chemistry, 35(2), 201-214. 
Leonard, J. P., Dos Santos, C. M. G., Plush, S. E., McCabe, T., \& Gunnlaugsson, T. (2007). pH driven self-assembly of a ternary lanthanide luminescence complex: the sensing of anions using a $\beta$-diketonate-Eu (III) displacement assay. Journal of the Chemical Society, Chemical Communications, 2, 129-131.

Lopez-Gonzalez, H., Jiménez-Reyes, M., Solache-Ríos, M., \& Rojas-Hernández, A. (2007). Solubility and hydrolysis of lutetium at different $\left[\mathrm{Lu}^{3+}\right]_{\text {initial . Journal of }}$ Radioanalytical and Nuclear Chemistry, 274(1), 103-108.

Parker, D., \& Yu, J. (2005). A pH-insensitive, ratiometric chemosensor for citrate using europium luminescence. The Royal Society Chemistry, Chemical Communications, 25, 3141-3143.

Ramírez-García, J. J., Jiménez-Reyes, M., Solache-Ríos, M., Fernández-Ramírez, E., López-González, H., \& Rojas-Hernández, A. (2003). Solubility and first hidrolysis constants of europium at different ionic strength and $303 \mathrm{~K}$. Journal of Radioanalytical and Nuclear Chemistry, 257(2), 299-303.

Sherry, A. D.; Yoshida, C.; Birbaun, E. R., \& Darnall, D. W., (1973). Nuclear magnetic resonance study of the interaction of neodymium (III) with amino acids and carboxylic acids. Aqueous shift reagent. Journal of the American Chemical Society, 95(9), 3011-3014.

Silber, H. B., Chang, T., \& Mendoza, E. (2001). Europium (III)-asparagine complexation in aqueous methanol. Journal of Alloys and Compounds, 323-324, 190-192.

Silber, H. B., \& Nguyen, Y. (1998). Lanthanide complexation with amino acids: Eu(III) with alanine in aqueous methanol. Journal of Alloys and Compounds, 275-277, 811-814.

Silber, B. H., Marachin, V., Paquette, S., \& Smith, S. (2004). Luminescence studies of lanthanide complexation reactions: europium (III) with saccharin in water. Journal of Alloys and Compounds, 374(1-2), 339-343.

Skoog, D. A., Holler, F. J., \& Nieman, A. T. (5 ${ }^{\text {th }}$ ed. ). (1998). Principles of Instrumental Analysis. Orlando, FL: Harcourt Brace \& Company, Chapter 15.

Skoog, D. A., Holler, F. J., \& Nieman, A. T. (5 ${ }^{\text {th }}$ ed.). (1998). Principles of Instrumental Analysis. Orlando, FL: Harcourt Brace \& Company, Chapter 16.

Stokes, G. G. (1852). On the Change of Refrangibility of Light. Philosophical Transactions of the Royal Society of London, 142, 463-562. 
Yang, C.; Fu, L. M.; Wang, Y.; Zhang, J. P.; Wong, W. T.; Ai, X. C.; Qiao, Y. F.; Zou, B. S.; Gui, L. L. (2004). A highly luminescent europium complex showing visible-light-sensitized red emission: direct observation of the singlet pathway. Angewandte Chemie International Edition, 43(38), 5010-5013. 


\section{Appendices}

\section{APPENDIX A}

\section{Instrumental Constants}

1. At low $\mathrm{pH}(\mathrm{pH} \sim 5.0)$

$$
\begin{aligned}
& \mathrm{Eu}^{3+}+\mathrm{H}_{2} \mathrm{O} \rightleftharpoons \mathrm{EuOH}^{2+}+\mathrm{H}^{+} \\
& \mathrm{K}_{\mathrm{OH}}=\frac{\left[\mathrm{EuOH}^{2+}\right]\left[\mathrm{H}^{+}\right]}{\left[\mathrm{Eu}^{3+}\right]} \quad ; \quad \mathrm{K}_{\mathrm{OH}}=10^{7.41}=3.89 \times 10^{-8} \\
& {\left[\mathrm{EuOH}^{2+}\right]=\frac{\mathrm{K}_{\mathrm{OH}}\left[\mathrm{Eu}^{3+}\right]}{\left[\mathrm{H}^{+}\right]} \quad ; \quad\left[\mathrm{H}^{+}\right]=4.08 \times 10^{-8} \mathrm{M}} \\
& {\left[\mathrm{EuOH}^{2+}\right]=1.07 \times 10^{-3} \mathrm{M} \quad ; \quad\left[\mathrm{Eu}^{3+}\right]=1.12 \times 10^{-3} \mathrm{M}}
\end{aligned}
$$

Find instrument constants, $\mathrm{k}_{\mathrm{o}}, \mathrm{k}_{\mathrm{Eu}}$ :

$$
\begin{aligned}
& \mathrm{I}=\mathrm{k}_{\mathrm{o}}+\mathrm{k}_{\mathrm{Eu}}[\mathrm{Eu}] \quad \mathrm{I}=7.41 \times 10^{6} \mathrm{X}+5.27 \times 10^{3} \\
& \mathrm{k}_{\mathrm{Eu}}=7.41 \times 10^{6} \\
& \mathrm{k}_{\mathrm{o}}=5.27 \times 10^{3}
\end{aligned}
$$

2. At high $\mathrm{pH}(\mathrm{pH} \sim 7.4)$

$$
\begin{aligned}
\mathrm{Eu}+\mathrm{L} \rightleftharpoons \mathrm{EuL} & \text { (for clarity, charges were neglected) } \\
\mathrm{K}_{\mathrm{EuL}}=\frac{[\mathrm{EuL}]}{[\mathrm{Eu}][\mathrm{L}]} & ;[\mathrm{EuL}]=3.15 \times 10^{-4} \mathrm{M} \\
\text { estimated } \mathrm{K}_{\mathrm{EuL}} \text { value } &
\end{aligned}
$$

Calculations of instrument constants, $\mathrm{k}_{\mathrm{o}}, \mathrm{k}_{\mathrm{Eu}}, \mathrm{k}_{\mathrm{EuOH}}, \mathrm{k}_{\mathrm{EuL}}$ : 


$$
\begin{aligned}
& \mathrm{I}_{\mathrm{o}}=\mathrm{k}_{\mathrm{o}}+\mathrm{k}_{\mathrm{Eu}}[\mathrm{Eu}]+\mathrm{k}_{\mathrm{EuOH}}[\mathrm{EuOH}] \\
& \mathrm{k}_{\mathrm{EuOH}}=\frac{\mathrm{I}_{0}-\mathrm{k}_{0}-\mathrm{k}_{\mathrm{Eu}}[\mathrm{Eu}]}{[\mathrm{EuOH}]}=1.04 \times 10^{7} \\
& \mathrm{I}^{\prime}=\mathrm{I}-\mathrm{k}_{\mathrm{o}}-\mathrm{k}_{\mathrm{Eu}}[\mathrm{Eu}]-\mathrm{k}_{\mathrm{EuOH}}[\mathrm{EuOH}]=\mathrm{k}_{\mathrm{EuL}}[\mathrm{EuL}] \\
& \mathrm{k}_{\mathrm{EuL}}=\frac{\mathrm{I}-\mathrm{k}_{\mathrm{o}}-\mathrm{k}_{\mathrm{Eu}}[\mathrm{Eu}]-\mathrm{k}_{\mathrm{EuOH}}[\mathrm{EuOH}]}{[\mathrm{EuL}]}
\end{aligned}
$$




\section{APPENDIX B}

\section{Ionic Strength}

$$
\begin{aligned}
& \mathrm{I}=1 / 2 \Sigma\left(\mathrm{Z}_{\mathrm{i}}^{2} \times \mathrm{C}_{\mathrm{i}}\right) \\
& \mathrm{Eu}(\mathrm{OTf})_{3} \rightarrow \mathrm{Eu}^{3+}+\mathrm{OTf}^{-} \\
& \mathrm{I}=1 / 2\left[\left(3^{2} \times \mathrm{C}_{\mathrm{Eu}}\right)+\left(1^{2} \times \mathrm{C}_{\mathrm{OTf}}\right)\right] ; \\
& \mathrm{I}=0.015 \mathrm{M} ;
\end{aligned}
$$

where $\mathrm{C}_{\mathrm{OTf}}=3 \mathrm{C}_{\mathrm{Eu}}$

where $\mathrm{C}_{\mathrm{Eu}}=0.0025 \mathrm{M}$ 


\section{APPENDIX C}

\section{Additional Tables}

Table 1: Stock Solution Dilutions.

\begin{tabular}{|c|c|c|c|c|c|c|}
\hline \multirow[t]{2}{*}{ Solution \# } & \multicolumn{2}{|c|}{$\begin{array}{l}\text { Stock Solution, } \\
0.0505 \mathrm{M}\left[\mathrm{Eu}^{3+}\right]\end{array}$} & \multicolumn{2}{|c|}{$\begin{array}{l}\text { Stock Solution, 0.100M } \\
\text { [D-glucosamine] }\end{array}$} & \multicolumn{2}{|c|}{$\begin{array}{l}\text { Stock Solution, } \\
2.00 \mathrm{M}\left[\mathrm{NaClO}_{4}\right]\end{array}$} \\
\hline & {$\left[\mathbf{E u}^{3+}\right], \mathbf{M}$} & $\begin{array}{l}\text { Vol, } \\
\text { mL }\end{array}$ & [D-gluco], M & Vol, mL & $\begin{array}{l}{\left[\mathrm{NaClO}_{4}\right],} \\
\mathrm{M}\end{array}$ & $\begin{array}{l}\text { Vol, } \\
\text { mL }\end{array}$ \\
\hline 1 & 0.0025 & 0.495 & 0.00076 & 0.076 & 0.085 & 0.425 \\
\hline 2 & 0.0025 & 0.495 & 0.0010 & 0.100 & 0.085 & 0.425 \\
\hline 3 & 0.0025 & 0.495 & 0.0020 & 0.200 & 0.085 & 0.425 \\
\hline 4 & 0.0025 & 0.495 & 0.0030 & 0.300 & 0.085 & 0.425 \\
\hline 5 & 0.0025 & 0.495 & 0.0040 & 0.400 & 0.085 & 0.425 \\
\hline
\end{tabular}

Table 2: Initial Data Points of 0.0025 M Eu(III) - D-glucosamine.

\begin{tabular}{|l|l|l|}
\hline [D-glucosamine], M & $\begin{array}{l}\text { Intensity @ 614 nm at } \mathbf{p H}< \\
\mathbf{5 . 0}\end{array}$ & $\begin{array}{l}\text { Intensity @ 614 nm at } \\
\mathbf{p H} \sim 7.4\end{array}$ \\
\hline 0.00076 & 16988 & 64086 \\
\hline 0.0010 & 16139 & 85551 \\
\hline 0.0020 & 16996 & 87586 \\
\hline 0.0030 & 17491 & 139815 \\
\hline 0.0040 & 17571 & 170695 \\
\hline
\end{tabular}


Table 3: Initial Data Points of 0.0025 M Eu(III) - Monosaccharide at pH 7.4.

\begin{tabular}{|c|c|c|c|c|c|}
\hline \multicolumn{2}{|l|}{ Galactose } & \multicolumn{2}{|l|}{ Mannose } & \multicolumn{2}{|l|}{ Ribose } \\
\hline $\begin{array}{l}\text { Concentration } \\
\text { (M) }\end{array}$ & Intensity & $\begin{array}{l}\text { Concentration } \\
\text { (M) }\end{array}$ & Intensity & $\begin{array}{l}\text { Concentration } \\
\text { (M) }\end{array}$ & Intensity \\
\hline 0.00035 & 25797 & 0.00035 & 26600 & 0.00035 & 26111 \\
\hline 0.00075 & 28892 & 0.00075 & 29952 & 0.00075 & 31159 \\
\hline 0.0010 & 23968 & 0.0010 & 26757 & 0.0010 & 27764 \\
\hline 0.0030 & 34323 & 0.0030 & 30958 & 0.0030 & 35126 \\
\hline 0.0050 & 37526 & 0.0050 & 34863 & 0.0050 & 37449 \\
\hline 0.0065 & 38174 & 0.0065 & 37028 & 0.0065 & 41555 \\
\hline 0.0075 & 41307 & 0.0075 & 32026 & 0.0075 & 46631 \\
\hline 0.0095 & 48898 & 0.0095 & 37899 & 0.0095 & 48085 \\
\hline 0.0105 & 52685 & 0.0105 & 41047 & 0.0105 & 56245 \\
\hline 0.0120 & 50330 & 0.0120 & 42917 & 0.0120 & 56353 \\
\hline 0.0150 & 51734 & 0.0150 & 42154 & 0.0150 & 56665 \\
\hline 0.0175 & 58515 & 0.0175 & 47487 & 0.0175 & 60514 \\
\hline 0.0200 & 71278 & 0.0200 & 47836 & 0.0200 & 70362 \\
\hline 0.0230 & 75194 & 0.0230 & 52001 & 0.0230 & 73089 \\
\hline 0.0250 & 76932 & 0.0250 & 53671 & 0.0250 & 74866 \\
\hline
\end{tabular}

Table 5: Data Points of 0.0025 M Eu(III)- D-glucosamine at Wavelength of 614 nm.

\begin{tabular}{|l|l|l|l|l|}
\hline $\begin{array}{l}\text { Number of } \\
\text { Scanning }\end{array}$ & {$[\mathbf{E u}]_{\mathbf{t}}(\mathbf{M})$} & {$[\text { Ligand }]_{\mathbf{t}}(\mathbf{M})$} & $\mathbf{p H}$ & $\begin{array}{l}\text { Measured Intensity } \\
(\mathbf{c p s})\end{array}$ \\
\hline 1 & 0.0025 & 0.00010 & 7.40 & 32980 \\
\hline 2 & 0.0025 & 0.00035 & 7.37 & 28914 \\
\hline 3 & 0.0025 & 0.00050 & 7.35 & 32281 \\
\hline 4 & 0.0025 & 0.00075 & 7.37 & 30112 \\
\hline 5 & 0.0025 & 0.00080 & 7.35 & 31246 \\
\hline 6 & 0.0025 & 0.00095 & 7.38 & 33670 \\
\hline
\end{tabular}




\begin{tabular}{|c|c|c|c|c|}
\hline 7 & 0.0025 & 0.00100 & 7.38 & 32831 \\
\hline 8 & 0.0025 & 0.00150 & 7.38 & 34930 \\
\hline 9 & 0.0025 & 0.00200 & 7.37 & 34190 \\
\hline 10 & 0.0025 & 0.00250 & 7.39 & 50624 \\
\hline 11 & 0.0025 & 0.00300 & 7.36 & 46799 \\
\hline 12 & 0.0025 & 0.00350 & 7.39 & 45750 \\
\hline 13 & 0.0025 & 0.00400 & 7.40 & 59818 \\
\hline 14 & 0.0025 & 0.00450 & 7.38 & 55221 \\
\hline 15 & 0.0025 & 0.00500 & 7.39 & 58279 \\
\hline 16 & 0.0025 & 0.00600 & 7.40 & 51011 \\
\hline 17 & 0.0025 & 0.00650 & 7.36 & 64838 \\
\hline 18 & 0.0025 & 0.00700 & 7.38 & 65997 \\
\hline 19 & 0.0025 & 0.00750 & 7.43 & 76930 \\
\hline 20 & 0.0025 & 0.00800 & 7.37 & 73796 \\
\hline 21 & 0.0025 & 0.00850 & 7.40 & 86096 \\
\hline 22 & 0.0025 & 0.00900 & 7.40 & 66561 \\
\hline 23 & 0.0025 & 0.00950 & 7.37 & 87681 \\
\hline 24 & 0.0025 & 0.01000 & 7.38 & 91403 \\
\hline 25 & 0.0025 & 0.01050 & 7.40 & 90980 \\
\hline 26 & 0.0025 & 0.01100 & 7.40 & 114611 \\
\hline 27 & 0.0025 & 0.01150 & 7.40 & 112000 \\
\hline 28 & 0.0025 & 0.01200 & 7.40 & 104295 \\
\hline 29 & 0.0025 & 0.01250 & 7.39 & 106520 \\
\hline 30 & 0.0025 & 0.01300 & 7.38 & 112797 \\
\hline 31 & 0.0025 & 0.01350 & 7.40 & 127576 \\
\hline 32 & 0.0025 & 0.01400 & 7.40 & 103845 \\
\hline 33 & 0.0025 & 0.01450 & 7.40 & 129344 \\
\hline 34 & 0.0025 & 0.01500 & 7.42 & 115031 \\
\hline 35 & 0.0025 & 0.01550 & 7.39 & 111557 \\
\hline
\end{tabular}




\begin{tabular}{|l|l|l|l|l|}
\hline 36 & 0.0025 & 0.01600 & 7.39 & 116499 \\
\hline 37 & 0.0025 & 0.01650 & 7.40 & 114272 \\
\hline 38 & 0.0025 & 0.01700 & 7.40 & 127590 \\
\hline 39 & 0.0025 & 0.01750 & 7.40 & 111208 \\
\hline 40 & 0.0025 & 0.01800 & 7.38 & 119427 \\
\hline 41 & 0.0025 & 0.01850 & 7.38 & 120572 \\
\hline 42 & 0.0025 & 0.01900 & 7.41 & 144093 \\
\hline 43 & 0.0025 & 0.01950 & 7.42 & 133157 \\
\hline 44 & 0.0025 & 0.02000 & 7.38 & 138615 \\
\hline 45 & 0.0025 & 0.02100 & 7.38 & 151257 \\
\hline 46 & 0.0025 & 0.02200 & 7.41 & 144205 \\
\hline 47 & 0.0025 & 0.02300 & 7.41 & 148912 \\
\hline 48 & 0.0025 & 0.02400 & 7.41 & 134986 \\
\hline 49 & 0.0025 & 0.02500 & 7.40 & 144823 \\
\hline
\end{tabular}

